\title{
Variation of concentrations and physicochemical properties of aeolian dust obtained in east China and Japan from 2001 to 2002
}

\author{
Yutaka Kanai $^{1,2 \star}$, Atsuyuki Ohta ${ }^{2}$, Hikari Kamioka ${ }^{1}$, Shigeru Terashima ${ }^{2}$, Noboru Imai ${ }^{2}$, \\ Yukihiro Matsuhisa ${ }^{2}$, Michiyo Kanai ${ }^{2}$, Hiroshi Shimizu ${ }^{2,3}$, Yoshio Takahashi ${ }^{2,3}$, Kenji Kai ${ }^{4}$, \\ Boyu Xu' ${ }^{4}$ Masahiko Hayashi ${ }^{5}$, and Renjian Zhang $^{6}$ \\ Yutaka Kanai, Atsuyuki Ohta, Hikari Kamioka, Shigeru Terashima, Noboru Imai, Yukihiro Matsuhisa, \\ Michiyo Kanai, Hiroshi Shimizu, Yoshio Takahashi, Kenji Kai, Boyu Xu, Masahiko Hayashi, and Renjian Zhang \\ (2003) Variation of concentrations and physicochemical properties of aeolian dust obtained in east China and \\ Japan from 2001 to 2002. Bull. Geol. Surv. Japan, vol. 54 (7/8), 251-267, 8 figs, 4 tables, appendix 3.
}

\begin{abstract}
In order to clarify the variation and characterization of dust particles, we started the JapanChina joint project, "Studies on origin and transport of aeolian dust and its impact on climate". We set up sampling instruments in Beijing, Qingdao and Hefei in China and Naha, Fukuoka, Nagoya and Tsukuba in Japan and collected aeolian dust that originated in the desert area of western China. In this study, we collected the aeolian dust from February 2001 to May 2002 and studied the monthly variation of dust concentrations.

The one-year observation data show that the aerosol has a bimodal size distribution (one peak at around $0.5 \mu \mathrm{m}$ corresponds to particles of anthropogenic origin and another peak at around 4-5 $\mu \mathrm{m}$ reflects aeolian dust of continental origin) and the coarser particles increased when a dust event occurred.

The seasonal variations of dust concentration showed that the aeolian dust content in spring is higher than other seasons. It sometimes became high in winter in Qingdao.

The aerosol concentration under usual conditions at each observation station in Japan does not differ so much, however that in China is larger than in Japan. During the intensive observation period (April 2002) when a dust storm event occurred in China, the coarser fraction increased in grain size, and the average dust concentration increased. The aerosol concentration seems to be in the order of Beijing $>$ Qingdao $>$ Hefei and Beijing $>$ Fukuoka $>$ Nagoya $>$ Tsukuba $>$ Naha.

The main chemical components of water-soluble fraction are supposed to be $\left(\mathrm{NH}_{4}\right)_{2} \mathrm{SO}_{4}$ in finer particles and $\mathrm{Ca}\left(\mathrm{NO}_{3}\right)_{2}, \mathrm{CaCl}_{2}, \mathrm{NaNO}_{3}$ and $\mathrm{NaCl}$ in coarser particles. Aluminum content in waterinsoluble fraction was high in coarser particles, and this confirmed that they consist of a mineral component.
\end{abstract}

Keywords: sampling, grain-size distribution, concentration, aeolian dust, Kosa, Naha, Fukuoka,Nagoya, Tsukuba, Qingdao, Beijing, Hefei.

\section{Introduction}

"Kosa" is the heavy aeolian dust that is transported from the arid and semi-arid regions in northwest China to Japan during spring. In order to observe the occurrence and transport of dust systematically and devise a prediction model in cooperation with China, we started the Japan-China joint project, "Studies on ori- gin and transport of aeolian dust and its impact on climate" (Kanai, 2001).

The aim of this project is to obtain precise observation data and make a quantitative prediction model for the estimation of climate change. The mineral dust is considered to have a great influence on global climate as shown by the report of IPCC (Intergovernmental Panel on Climate Change). However, the radiative

\footnotetext{
${ }^{1}$ Research Center for Deep Geological Environments, GSJ, AIST Central 7, Higashi 1-1-3, Tsukuba, 305-8567, Japan

${ }^{2}$ Institute of Geoscience, GSJ, AIST Central 7, Higashi 1-1-3, Tsukuba, 305-8567, Japan

${ }^{3}$ Hiroshima Univ., 1-3-1 Kagamiyama, Higashi-Hiroshima 739-8526, Japan

${ }^{4}$ Nagoya Univ., Furo-cho, Chikusa-ku, Nagoya 464-8601, Japan

${ }^{5}$ Fukuoka Univ., 8-19-1 Nanakuma, Jonan-ku, Fukuoka 814-0180, Japan

${ }^{6}$ Institute of Atmospheric Physics, Chinese Academy of Sciences, Beijing 100029 P.R. China

* corresponding author Tel: 029-861-3865, Fax: 029-861-3752
} 
forcing effect by mineral aerosol has uncertainty and is not clearly elucidated. Although Asian dust has a significant influence on the global climate, little study on the systematic observation has been conducted. Nishikawa et al. (1987) and Zhang and Iwasaka (1998) studied the chemical composition of atmospheric aerosols, and Zhang et al. (1997) studied the dust from the Chinese desert area. The National Institute for Environmental Studies (2001) reported the observations of atmospheric aerosols in China from the point of view of atmospheric pollution. But systematic studies on physical and chemical characteristics of aeolian dust are desired because the modeling of radiative effects by aerosol needs information on the size distribution, mineral composition and other factors.

This research project is carried out by three subgroups: the first sub-group (G1) is an in site observation group for dust generation research, the second sub-group (G2) is a network observation group for dust transport research, and the third sub-group (G3) is a modeling group (Mikami et al., 2002). We belong to the second group (G2) that works for the network observation for a long-range dust transport. The G2 group involves the lidar observation for detecting a dust layer within the atmosphere, radiometric observation for optical thickness and dust size information, satellite analysis for horizontal dust distribution and dust particle sampling for physicochemical properties. We carried out a share of the dust sampling in east China and Japan.

A preliminary observation system was established in 2001 to obtain continuous and precise data on aeolian dust from China. We set up sampling instruments in Qingdao in China and Naha, Fukuoka, Nagoya and Tsukuba in Japan. We started to collect aeolian dust that originates in the desert area of western China. Preliminary results were reported in a previous paper (Kanai et al., 2002a; 2002b). Aeolian dust collected from the source region in northwestern China is studied by the Yabuki group (Yabuki et al., 2002).

In this study, we set up additional sampling instruments in Beijing and Hefei in 2002 and established a much better system for systematic observation. We collected the aeolian dust systematically in the course of transportation from China to Japan from 2001 to 2002 including the first intensive observation period (IOP) (IOP-1: April 2002). We report here the results of continuous observation from February 2001 to May 2002 and studied the annual variation of dust concentrations and properties. The detailed studies on chemical compositions of aeolian dust will be written in the other papers (Ohta et al., 2003; Kamioka et al. in preparation).

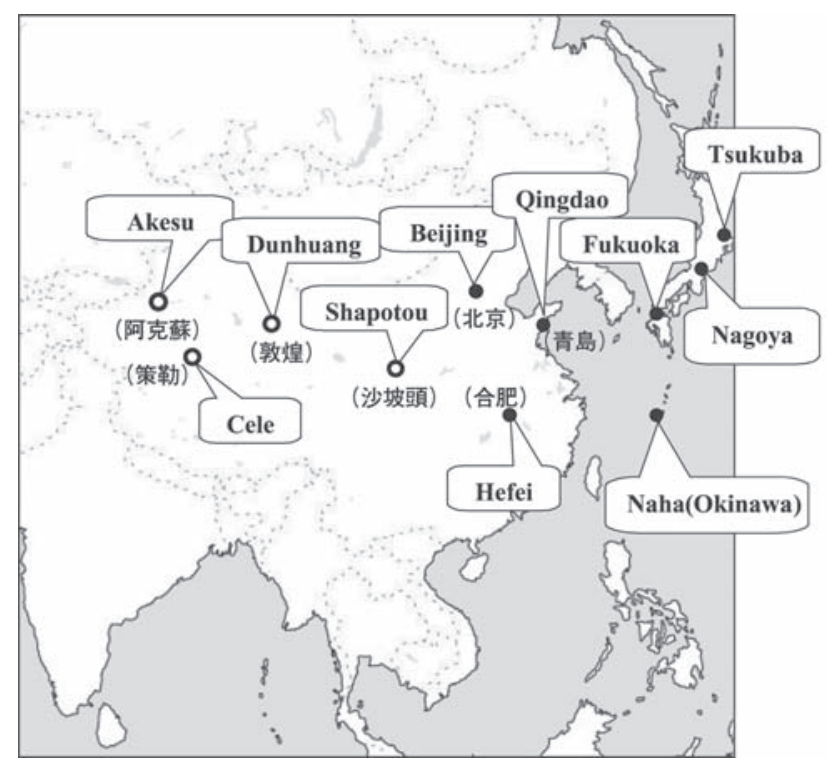

Fig. 1 Map of sampling locations. Solid circles represent our observation stations for the transportation study. Open circles are observation stations of the research group for the source area (Yabuki et al., 2002).

\section{Sampling locations and samples}

Seven observation stations for aeolian dust sampling were selected in China and Japan as shown in Fig. 1. Among them, three stations in eastern China are in Qingdao, Beijing and Hefei, and the other stations are in Naha (Okinawa), Fukuoka, Nagoya and Tsukuba in Japan. The detailed information of these locations is shown in Table 1.

The sampling instruments such as low-volume and high-volume air samplers and sampling filters used in this study are the same as those written in a previous paper (Kanai et al., 2002a). The high-volume air sampler HV-1000F manufactured by Shibata Scientific Co. Ltd. is employed for the bulk sampling. One thousand liters per minute of air is sucked continuously and filtered using a PF040 polyflon filter $(25 \mathrm{~cm} \times 20 \mathrm{~cm})$ manufactured by Advantec Co., Ltd. The low-volume air sampler (Andersen type) AN- 200 manufactured by Shibata Scientific Co., Ltd. is employed, and the flow rate is maintained at $28.3 \mathrm{l} / \mathrm{m}$ to produce ideal size separation. It has eight stages with a back-up filter and is used in order to obtain grain size distribution data of aeolian dust. The particle size classification is $>11 \mu$ $\mathrm{m}$ (sampling stage 0), 11-7.0 $\mu \mathrm{m}$ (stage 1), 7.0-4.7 $\mu \mathrm{m}$ (stage 2), 4.7-3.3 $\mu \mathrm{m}$ (stage 3), 3.3-2.1 $\mu \mathrm{m}$ (stage 4), 2.1-1.1 $\mu \mathrm{m}$ (stage 5), 1.1-0.65 $\mu \mathrm{m}$ (stage 6), 0.65-0.43 $\mu \mathrm{m}$ (stage 7 ) and $<0.43 \mu \mathrm{m}$ (back-up filter). The filters used for AN-200 are PF050 polyflon filters with 80 $\mathrm{mm} \phi$ diameter are manufactured by Advantec Co., Ltd. for No. 0 - No. 6 stages. The 2500QAT-UP quartz filter is manufactured by Tokyo Dylec Co., Ltd. for 
Table 1 List of sampling locations.

\begin{tabular}{|c|c|c|c|c|}
\hline $\begin{array}{c}\text { Obsrervation } \\
\text { station }\end{array}$ & Location name & $\begin{array}{c}\text { Latitude } \\
(\mathrm{N})\end{array}$ & $\begin{array}{c}\text { Longitude } \\
(\mathrm{E})\end{array}$ & $\begin{array}{c}\text { Height (above } \\
\text { S.L. / m) }\end{array}$ \\
\hline Tsukuba & $\begin{array}{c}\text { Geological Survey } \\
\text { of Japan }\end{array}$ & 36.06 & 140.14 & 44 \\
\hline Nagoya & Nagoya University & 35.15 & 136.96 & 74 \\
\hline Fukuoka & Fukuoka University & 33.55 & 130.37 & 57 \\
\hline Naha & $\begin{array}{c}\text { Okinawa branch of } \\
\text { the Japan Weather } \\
\text { Association }\end{array}$ & 26.20 & 127.69 & 40 \\
\hline Beijing & $\begin{array}{c}\text { Institute of } \\
\text { Atmospheric Physics }\end{array}$ & 39.93 & 116.35 & 100 \\
\hline Qingdao & $\begin{array}{c}\text { Ocean University of } \\
\text { Qingdao }\end{array}$ & 30.07 & 120.33 & 80 \\
\hline Hefei & $\begin{array}{c}\text { Anhui Institute of } \\
\text { Optics and Fine } \\
\text { Mechanics }\end{array}$ & 31.90 & 117.16 & - \\
\hline
\end{tabular}

No. 7 stage and back-up filter.

The aeolian dust samples were collected for several days depending on the location. Under usual operation in Japan, the high-volume air sampler HV-1000F was operated for one week or 10 days then the filter was changed. The low-volume air sampler AN- 200 was operated for 2 weeks or 20 days then the filters were changed. In China, the sampling duration became shorter than in Japan. During IOP-1, the low-volume air sampler AN-200 was operated much shorter than usual in order to collect dust samples from each dust storm event.

Each filter was kept in a desiccator before and after sampling. The humidity in the laboratory room and balance chamber is thought to affect the data on the filter weight so the humidity was checked and recorded. The weight of the filter is measured before and after sampling, and the dust mass concentration in the air is calculated by dividing the weight difference by the air volume.

\section{Analytical procedure for chemical composition}

The dust samples were analyzed to determine the water-soluble and water-insoluble components. A quarter of the filter obtained by the low-volume air sampler AN-200 was soaked in a Teflon beaker with $1 \mathrm{ml}$ of ethanol and $25 \mathrm{ml}$ of Milli Q water. The ultrasonic cleaner was operated for 30 minutes, and the watersoluble component was leached. By filtering the solution with a $0.22 \mu \mathrm{m}$ membrane filter, the eluent and water- insoluble fractions were separated. The eluent was weighed and its chemical composition was determined by ion chromatography (IC). The water-insoluble fraction was decomposed with $\mathrm{HNO}_{3}-\mathrm{HClO}_{4}-$
HF mixed acid and its composition was determined by Inductively Coupled Plasma Optical Emission Spectrometry (ICP-OES) and Mass Spectrometry (ICP-MS). The principal ions or elements determined for the water-soluble fraction are $\mathrm{Cl}^{-}, \mathrm{NO}_{3}{ }^{-}, \mathrm{SO}_{4}{ }^{2-}, \mathrm{NH}_{4}^{+}, \mathrm{Na}^{+}$, $\mathrm{K}^{+}, \mathrm{Ca}^{2+}$ and $\mathrm{Mg}^{2+}$, and those for the water-insoluble fraction are $\mathrm{Al}, \mathrm{Ti}, \mathrm{Na}$, $\mathrm{K}, \mathrm{Ca}, \mathrm{Mg}, \mathrm{Fe}, \mathrm{Mn}$ and several minor elements.

\section{Results and discussion}

\subsection{Variation of aeolian dust con- centration}

The observation of aeolian dust particles started from February 2001 in Tsukuba and Naha, March 2001 in Nagoya, April 2001 in Fukuoka, May 2001 in Qingdao, and March 2002 in Beijing and Hefei. The high-volume air sampler data show the average dust mass concentration in the air during an operation period. The results of each observation station are shown in Fig. 2 (see appendix 1). The results in spring are typically high. The concentration at each observation station is shown in a figure in Fig. 3 so these differences among the stations can be investigated. During the usual observation period, the differences of dust concentrations at four stations in Japan are not so large compared with the differences between China and Japan. Table 2 shows the average dust concentrations from June - October 2001 in Tsukuba, Nagoya, Fukuoka, Naha and Qingdao. They range from $23 \mu \mathrm{g} / \mathrm{m}^{3}$ to $88 \mu \mathrm{g} / \mathrm{m}^{3}$. However, there exists no difference among the average dust concentrations in Tsukuba, Nagoya and Fukuoka with $99.8 \%$ confidence by statistic testing. This might suggest that a substantial separation process of dust was achieved in China, and the dust particles that were transported to Japan are a nearly homogeneous mass.

Some large dust storm events occurred in March April 2002. Dust storms occurred on March $20^{\text {th }}$ and April $8^{\text {th }}$. The average dust concentrations of observations in March $19-22$ are $3510 \mu \mathrm{g} / \mathrm{m}^{3}(367-11600 \mu$ $\left.\mathrm{g} / \mathrm{m}^{3}\right)$ in Beijing, $604 \mu \mathrm{g} / \mathrm{m}^{3}\left(488-721 \mu \mathrm{g} / \mathrm{m}^{3}\right)$ in Qingdao, $240 \mu \mathrm{g} / \mathrm{m}^{3}\left(211-270 \mu \mathrm{g} / \mathrm{m}^{3}\right)$ in Hefei, $146 \mu$ $\mathrm{g} / \mathrm{m}^{3}$ in Fukuoka, $94 \mu \mathrm{g} / \mathrm{m}^{3}$ in Nagoya, $105 \mu \mathrm{g} / \mathrm{m}^{3}$ in Tsukuba and $63 \mu \mathrm{g} / \mathrm{m}^{3}$ in Naha. On the other hand, those of observations in April $8-12$ are $3410 \mu \mathrm{g} / \mathrm{m}^{3}$ (3010-3900 $\left.\mu \mathrm{g} / \mathrm{m}^{3}\right)$ in Beijing, $337 \mu \mathrm{g} / \mathrm{m}^{3}$ in Qingdao, $170 \mu \mathrm{g} / \mathrm{m}^{3}$ in Hefei, $245 \mu \mathrm{g} / \mathrm{m}^{3}$ in Fukuoka, $164 \mu \mathrm{g} / \mathrm{m}^{3}$ $\left(132-197 \mu \mathrm{g} / \mathrm{m}^{3}\right)$ in Nagoya, $123 \mu \mathrm{g} / \mathrm{m}^{3}\left(94-152 \mu \mathrm{g} / \mathrm{m}^{3}\right)$ in Tsukuba and $103 \mu \mathrm{g} / \mathrm{m}^{3}$ in Naha., Therefore, the average dust concentration during the dust storm events (March - April 2002) seems to be in the order of Beijing 


\section{(a) Japan}
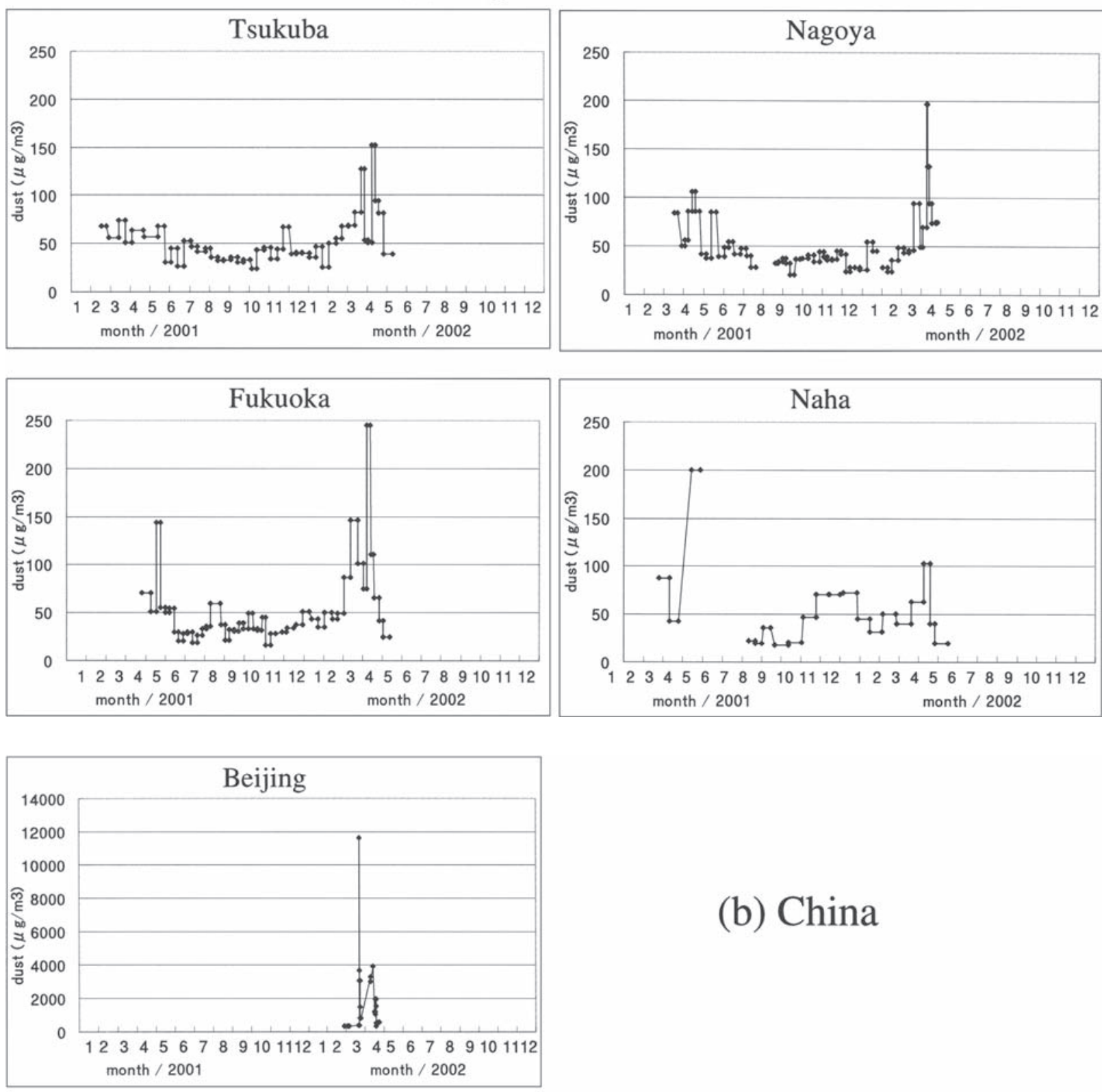

\section{(b) China}
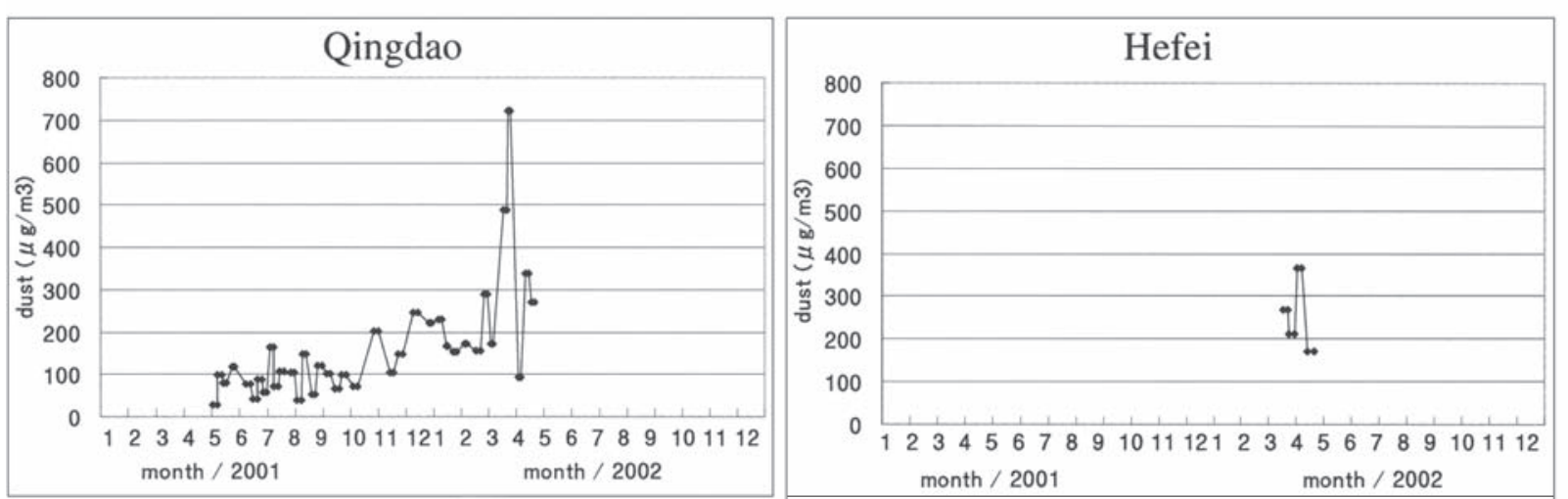

Fig. 2 Variation of aerosol concentration in

(a)Tsukuba, Nagoya, Fukuoka and Naha, Japan.

(b) Beijing, Qingdao and Hefei, China. 
Variation of concentrations and physicochemical properties of aeolian dust obtained in east China and Japan

from 2001 to 2002 (kanai et.al)

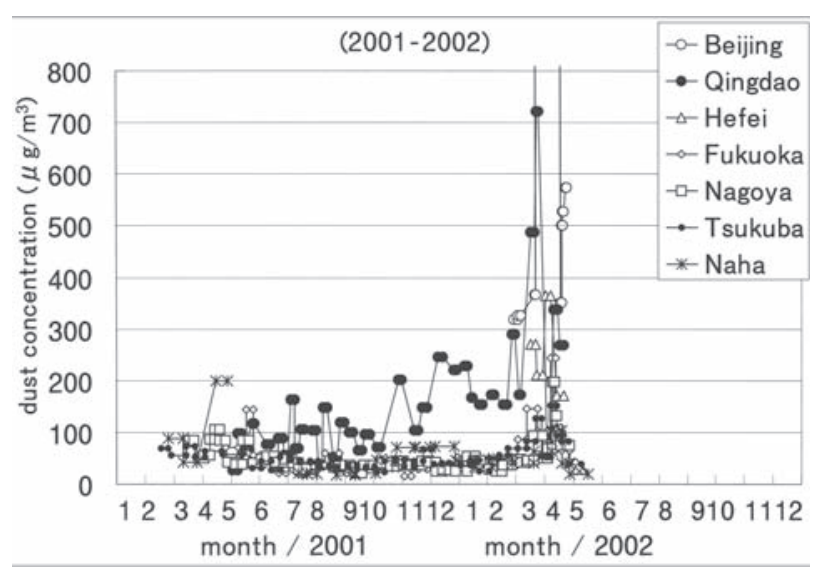

Fig. 3 Variation of aerosol concentration in seven observation stations. The concentration in Beijing increased up to $11600 \mu \mathrm{g} / \mathrm{m}^{3}$ in March, 2002.

$>$ Qingdao $>$ Hefei and Beijing $>$ Fukuoka $>$ Nagoya $>$ Tsukuba $>$ Naha. In Japan, the dust concentrations in the western area are higher than that in the eastern area (Kanai et al., 2002c). The reason is the dust is transported from China and the western area is much closer to the source. On the other hand, the dust concentration in Naha is smaller. Naha is south of Kyushu Island, far from Fukuoka. This fact suggests that the aeolian dust travels on an main path, which does not pass through Naha. The aeolian dust may be dispersed and diluted around Naha, and a low concentration was observed there.

\subsection{Aerosol size distribution}

The results of the annual observation of aerosol size distribution obtained using the Andersen-type low-volume air sampler are shown in Fig.4-6 for Fukuoka and Tsukuba in Japan, and Qingdao in China (see appendix 2). Fukuoka and Tsukuba are example stations of western area and eastern area of Japan, respectively. Qingdao is one example in China. The pattern of size distribution differs with place and time. However, a common feature of size distribution is found to be a bimodal distribution. It is already reported in a previous paper (Kanai et al., 2002a) that one peak at around $0.5 \mu \mathrm{m}$ corresponds to anthropogenic aerosol consisting mainly of carbon particles and another peak at around 4-5 $\mu \mathrm{m}$ contains aeolian dust particles, i.e. mineral particles transported from China.

In the spring, the dust concentration increases. The larger particles increase rather than smaller particles because the aeolian dust with larger particles is transported from western China by the prevailing westerlies. On the other hand, the finer particles increased in Qingdao in the winter, which suggests that the fine carbon aerosol increased from the combustion of coal.
Table 2. Average aeolian dust concentrations during June - September 2001 in Tsukuba, Nagoya, Fukuoka, Naha and Qingdao.

\begin{tabular}{|c|c|c|cc|}
\hline & Station & Duration & average concentration \\
& & & $\left(\mu \mathrm{g} / \mathrm{m}^{3}\right)$ & $\pm \sigma$ \\
\hline \multirow{3}{*}{ Japan } & Tsukuba & $6 / 1-10 / 1$ & $38.14 \pm$ & 7.85 \\
& Nagoya & $6 / 1-10 / 8$ & $37.56 \pm$ & 9.01 \\
& Fukuoka & $5 / 30-10 / 5$ & $34.08 \pm$ & 11.39 \\
& Naha & $7 / 10-10 / 1$ & $22.96 \pm$ & 7.40 \\
\hline China & Qingdao & $6 / 6-9 / 25$ & $88.06 \pm$ & 36.81 \\
\hline
\end{tabular}

\subsection{Chemical composition of aeolian dust}

The aerosol particles often contain sea salt. To evaluate the radiation force, it is necessary to determine both mineral and attached materials (i.e. salt). Therefore the chemical compositions of the water-soluble and water-insoluble fractions at each observation site are determined. Spanos et al.(2002) also considered the aerosol is affected by three factors: "sea spray", "soil dust" and "anthropogenic".

The sample amount we can obtain is very small so we need sensitive and excellent analytical techniques. IC, ICP-OES and ICP-MS were used in this study. At the same time, the blank test is important for the trace analysis. We planned to analyze the sample with the filter. The preliminary results for the blank test of filters are shown in Table 3. It indicates that the polyflon filter (PF050) and cellulose ester filter have few problems while the teflon-coated TF filter (T60A20) gives high blank values for $\mathrm{Al}, \mathrm{Na}, \mathrm{K}, \mathrm{Ca}$ and $\mathrm{Mg}$. The quartz filter (2500QAT) gives a little interference for the determination of $\mathrm{Al}$ if its content in the sample is low. We plan to analyze the carbon content using the quartz filter. Therefore, we decided to use the polyflon and quartz filters for sampling as mentioned above and subtract the blank concentration from the raw data for the correction.

The preliminary analyses for the water-soluble fraction are conducted, and the results are shown in Fig. 7. The detailed results will be reported elsewhere (Ohta et al., 2003; Kamioka et al. in preparation). The main components of the water-soluble fraction are composed

Table 3 Results of blank tests of filters.

\begin{tabular}{|c|c|c|c|c|c|}
\hline & & teflon-coated TF & quartz & polyflon & \\
\hline & & T60A20 & 2500QAT & PF050 & Cellulose ester \\
\hline $\mathrm{TiO}_{2}$ & $\%$ & 0.0273 & 0.0012 & 0.0001 & $<.0000$ \\
\hline $\mathrm{AbO}_{3}$ & $\%$ & 9.06 & 0.160 & $<.0000$ & 0.0007 \\
\hline total $\mathrm{Fel}_{2} \mathrm{O}_{3}$ & $\%$ & 0.0846 & 0.0253 & 0.0038 & $<.0000$ \\
\hline $\mathrm{MnO}$ & $\%$ & 0.0032 & 0.0008 & $<.0000$ & 0.0001 \\
\hline $\mathrm{MgO}$ & $\%$ & 1.58 & 0.0162 & $<.0000$ & 0.0054 \\
\hline $\mathrm{CaO}$ & $\%$ & 4.53 & 0.0318 & 0.0026 & 0.0089 \\
\hline $\mathrm{Na}_{2} \mathrm{O}$ & $\%$ & 9.24 & 0.0188 & $<.0000$ & $<.0000$ \\
\hline $\mathrm{K}_{2} \mathrm{O}$ & $\%$ & 3.99 & 0.0124 & $<.0000$ & $<.0000$ \\
\hline $\mathrm{P}_{2} \mathrm{O}_{5}$ & $\%$ & 0.0246 & 0.005 & $<.0000$ & 0.0006 \\
\hline
\end{tabular}




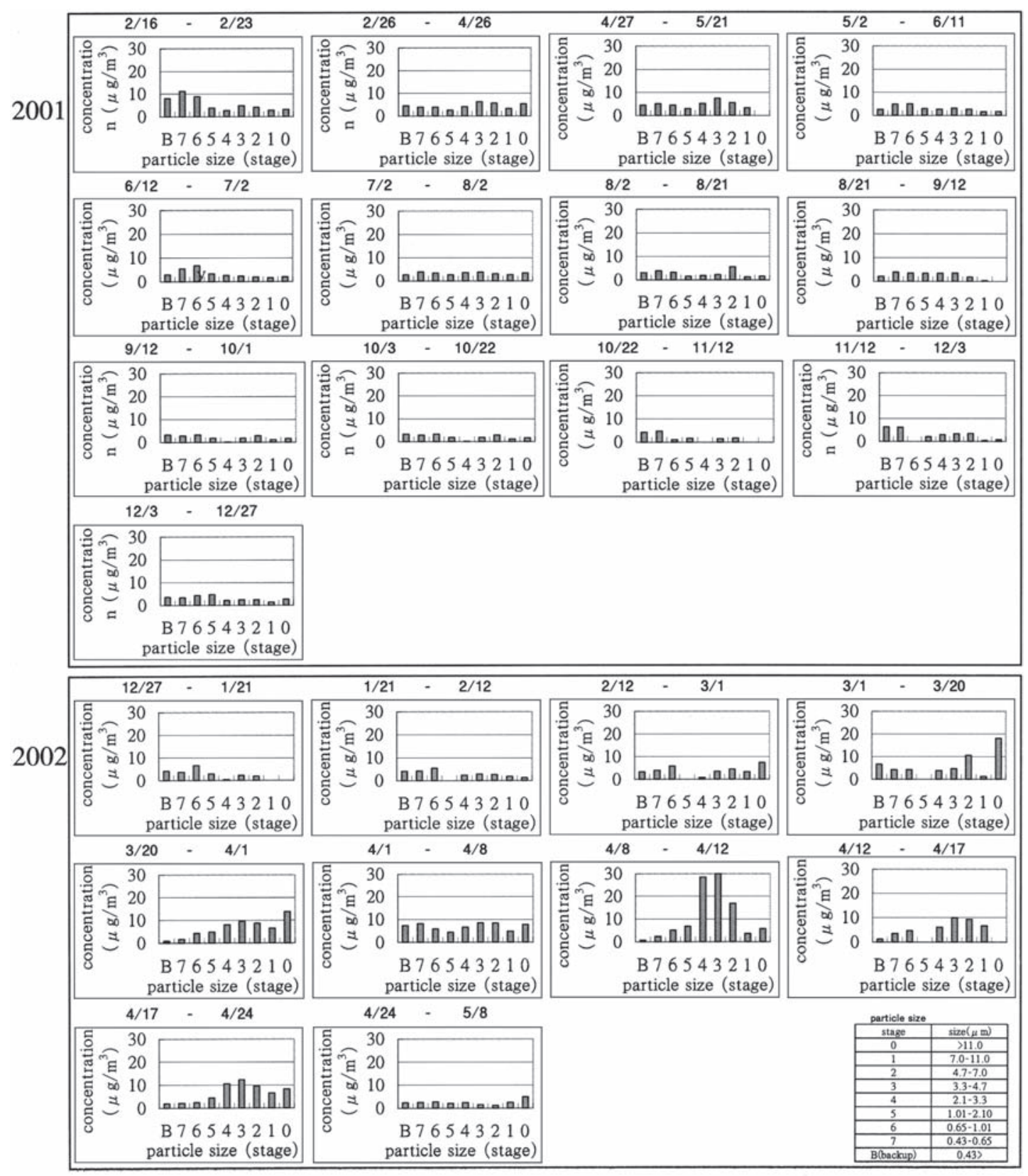

Fig. 4 Aerosol size distribution at Tsukuba city.

of some salts and vary with grain size. For the finer particles, the main cation is $\mathrm{NH}_{4}{ }^{+}$and main anion is $\mathrm{SO}_{4}{ }^{2-}$, the probability that $\left(\mathrm{NH}_{4}\right)_{2} \mathrm{SO}_{4}$ is crystallized is suggested. On the other hand, for the coarser particles, the main cations are $\mathrm{Na}^{+}$and $\mathrm{Ca}^{2+}$, and the dominant anions are $\mathrm{NO}_{3}{ }^{-}$and $\mathrm{Cl}^{-}$, probably forming $\mathrm{Ca}\left(\mathrm{NO}_{3}\right)_{2}$, $\mathrm{CaCl}_{2}, \mathrm{NaNO}_{3}$ and $\mathrm{NaCl}$ (Kanai et al., 2002c; Kamioka and Kanai, 2002). Whether these ions such as $\mathrm{NH}_{4}^{+}$ and $\mathrm{SO}_{4}^{2-}$ are of natural origin such as sea spray, volcanic and biogenic origin, or anthropogenic origin such as fertilizer is not clear, but most of $\mathrm{NaCl}$ will be originated from sea salt. The $\mathrm{NO}_{3}{ }^{-}$may be partially formed by the oxidation of air pollution materials (photochemical smog).
The variations of the elemental composition of water-insoluble components are shown in Fig. 8. They suggest the variation of mineral materials. For finer particles, most of the element concentrations are low. On the other hand, for the coarser particles larger than about 1-2 $\mu \mathrm{m}$ (sampling stage 4-5), the concentration is high. Mineral materials contain $\mathrm{Al}_{2} \mathrm{O}_{3}$ and $\mathrm{Al}_{2} \mathrm{O}_{3}$ is resistant to weathering. Its content is about $4-6 \%$ on a bulk weight basis. Although this value is lower than the average concentration of rocks (around 14\%), almost half of the aerosol component is in the watersoluble fraction. Therefore, the composition of the water-insoluble fraction will be compatible with that of rock if the concentration is calculated on a water- 

from 2001 to 2002 (kanai et.al)
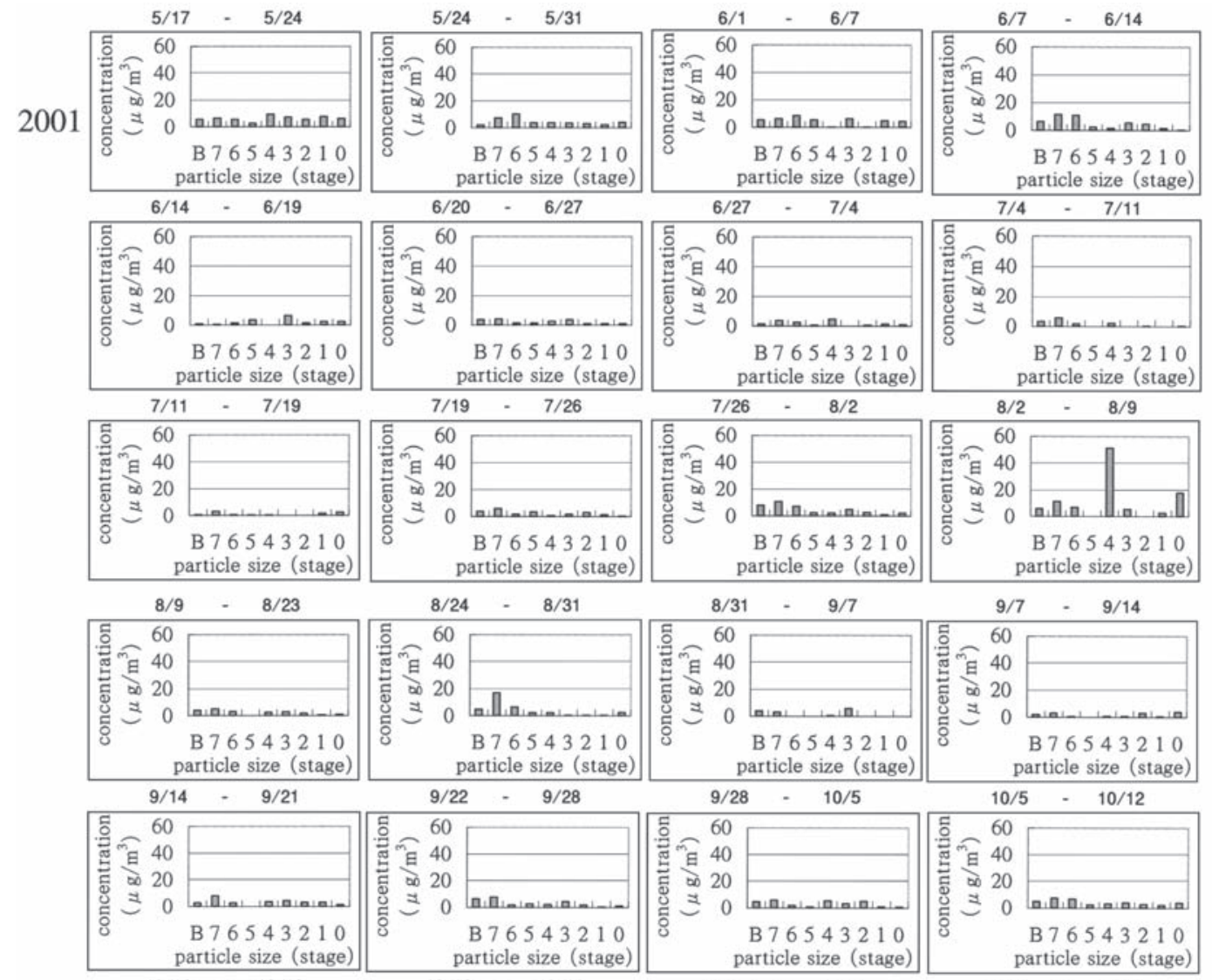

$9 / 28-10 / 5$
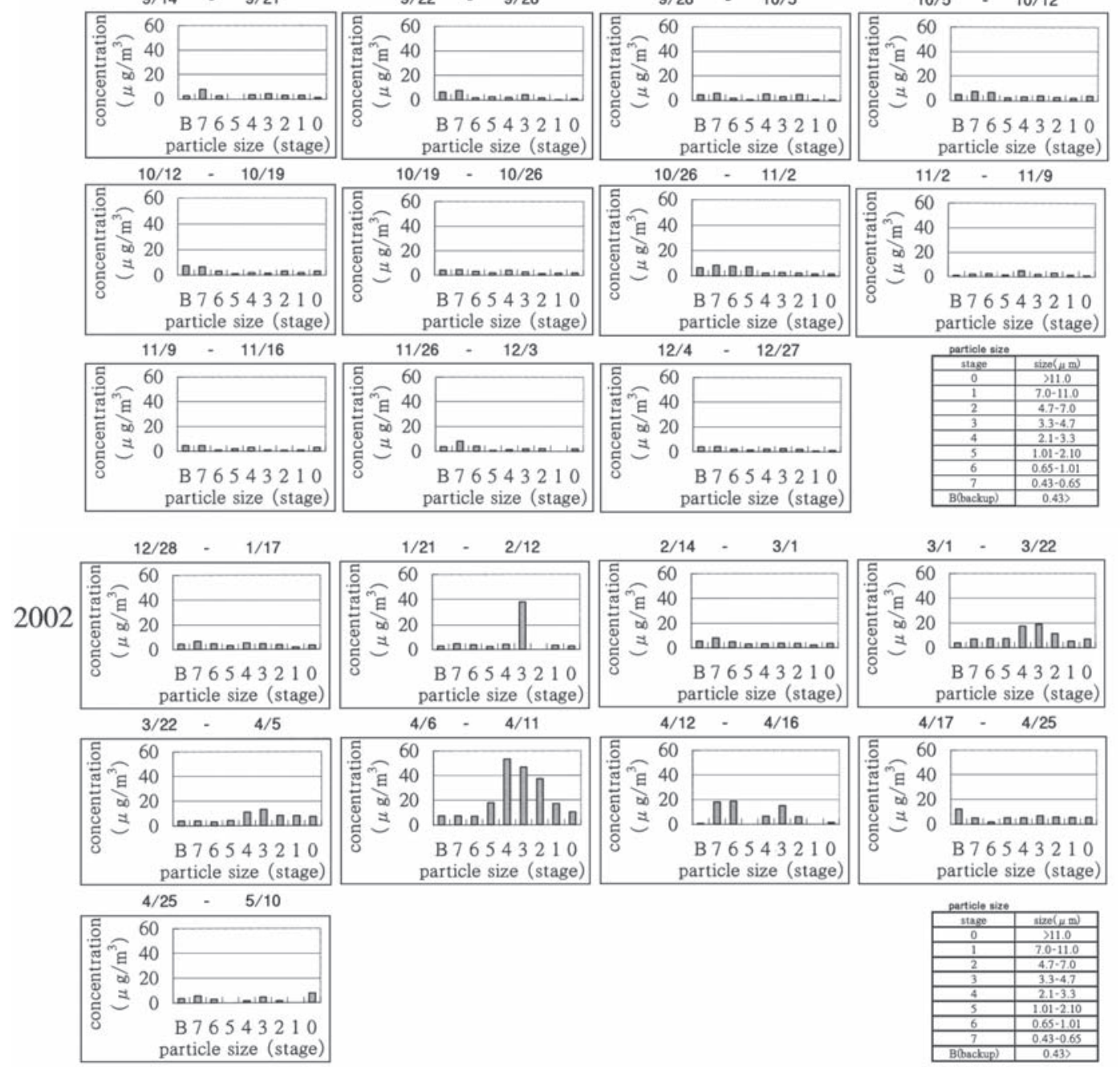

Fig. 5 Aerosol size distribution at Fukuoka city. 


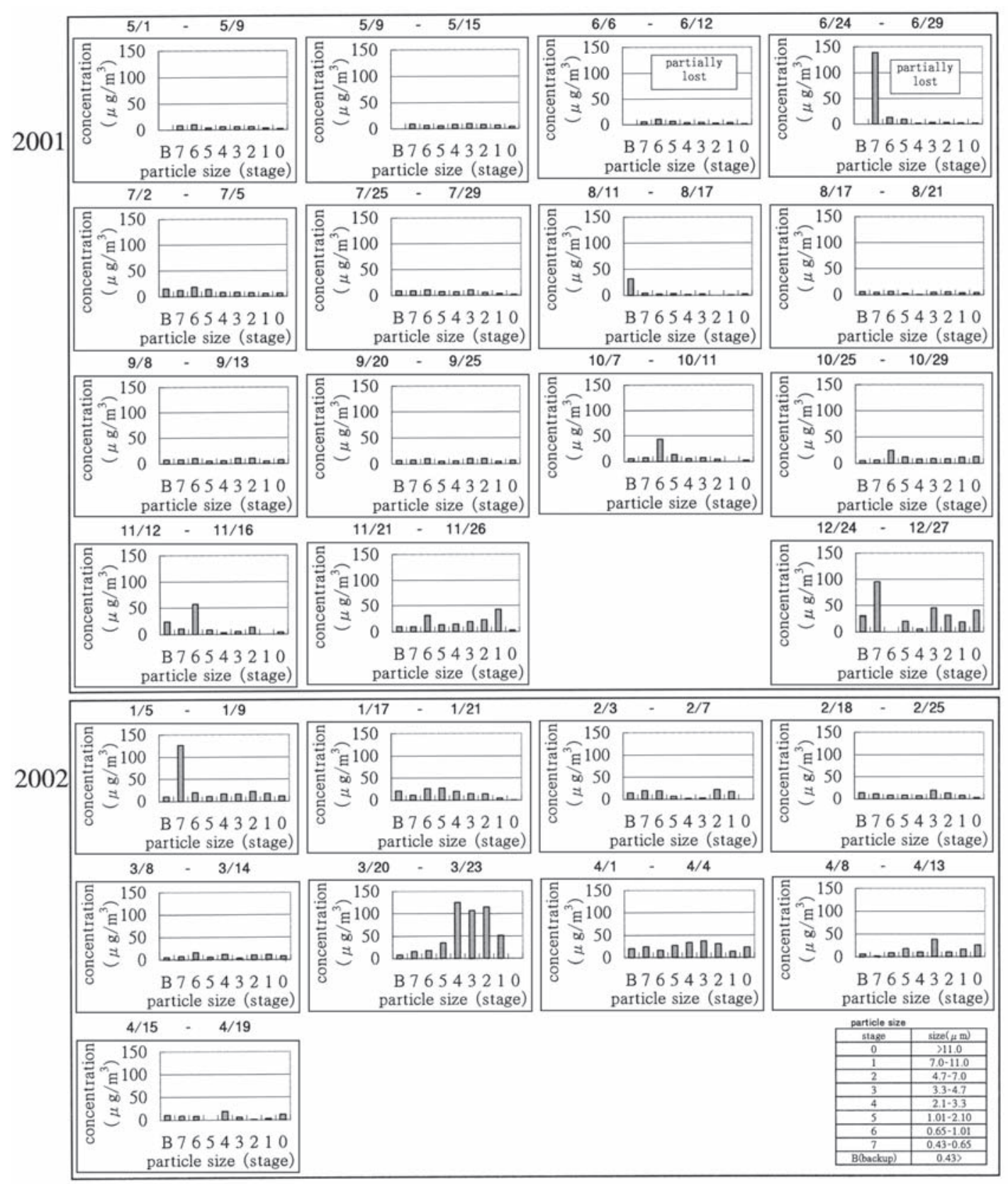

Fig. 6 Aerosol size distribution at Qingdao city.

insoluble fraction basis. These results confirm that the larger particles are composed of mineral materials. The detail study on the chemical compositions of aeolian dust will be shown by Ohta et al. (2003).

The black carbon, whose main source is anthropogenic, has a large effect on the radiation force. A quarter of the global output of black carbon is estimated to be from China (Streets et al., 2001) so it is important for our project, though it is not a mineral aerosol. We considered that the carbon content should be determined as well as the inorganic elements. The size of black carbon is very small, probably less than $1 \mu \mathrm{m}$. Therefore, the quartz filters are set for the back-up filter and stage No. 7 in order to collect the carbon. We plan to analyze the carbon content, and the results will be reported elsewhere. As mentioned above, the finer particles sometimes increased in Qingdao in the winter. It may suggest that the release of carbon increased in the winter from the use of coal. In Italy, the total carbon in aerosol is low in the summer and high in the winter, and $90-97 \%$ of total carbon is organic carbon (Decesari et al., 2001).

\subsection{Mineral composition of aeolian dust}

Aeolian dust contains the mineral particles that are supposed to be transported from China to Japan. Its mineralogical composition was determined by X-ray diffraction analysis after the particles were separated 
Variation of concentrations and physicochemical properties of aeolian dust obtained in east China and Japan from 2001 to 2002 (kanai et.al)
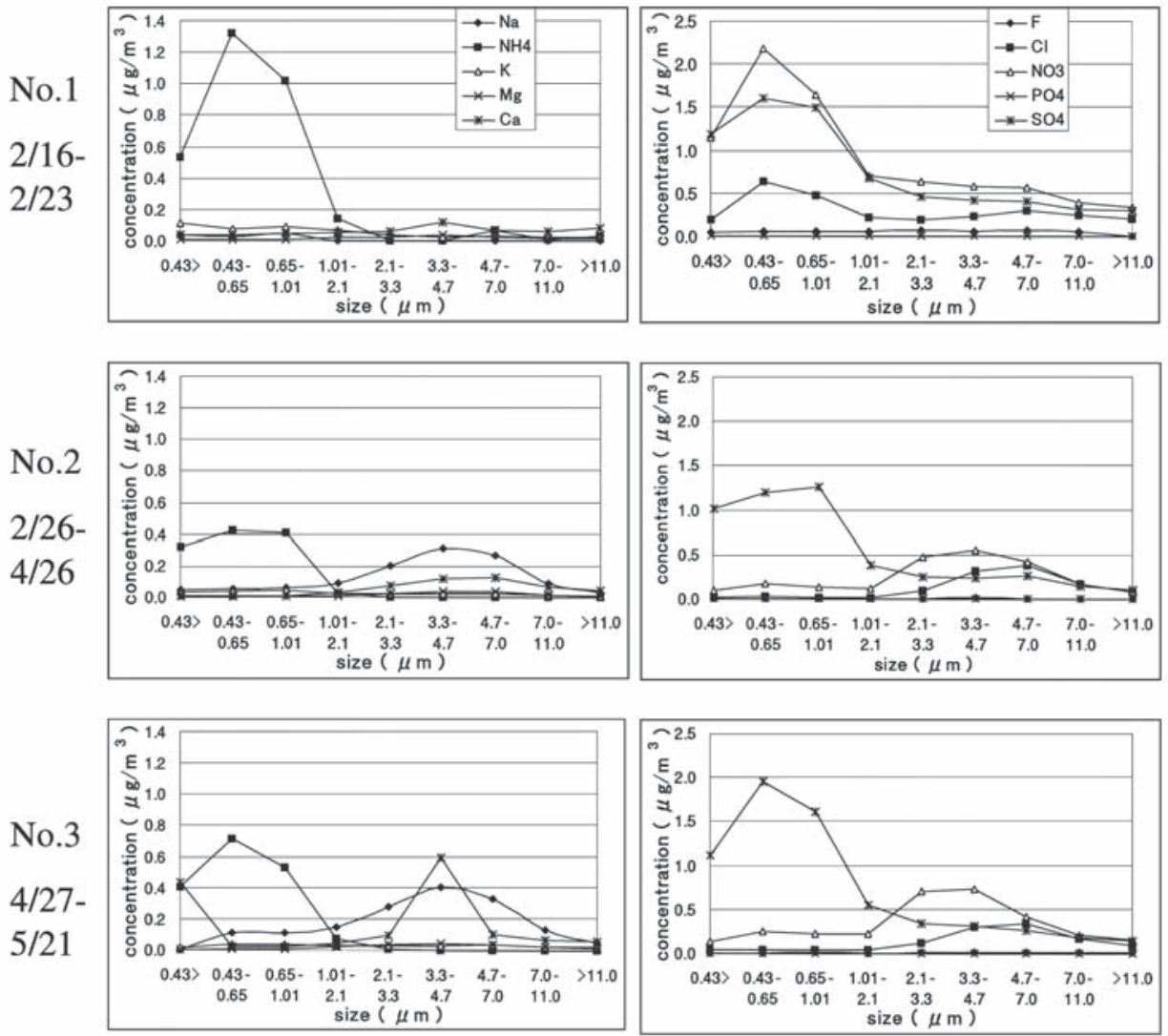

Fig. 7 Example of chemical composition of the water-soluble fraction in dust samples taken in Tsukuba, 2001.

from the filter with water and mounted on glass. The semi-quantitative results are shown in Table 4. Quartz is the main mineral that was found in all the samples tested. Other minerals such as mica, chlorite and feldspar were also found in almost all the samples. These minerals are rock-forming minerals and metamorphic minerals. Inoue and Mizota (1988) and Mizota and Inoue (1988) showed that the origin of the $14 \AA$ clay minerals in Japanese soils is aerosols of continental origin, and the oxygen isotope ratios of fine quartz in these minerals are nearly the same as those of loess in Asian Continent. To research the origin of these dusts, the isotopic analysis will be necessary, and it will be the next step of the research. Amorphous materials are also found in all the samples. These are very fine and easily transported by the wind. However, no distinct relationship can be found among the dust amount, observation stations, collection periods and minerals.

\subsection{Observation during IOP-1(April in 2002)}

In April 2002, the first intensive observation period (IOP-1;April 8 - 21) was settled and we started to observe a dust event and tried to take dust samples at each sampling station that we had already established as a sampling network.
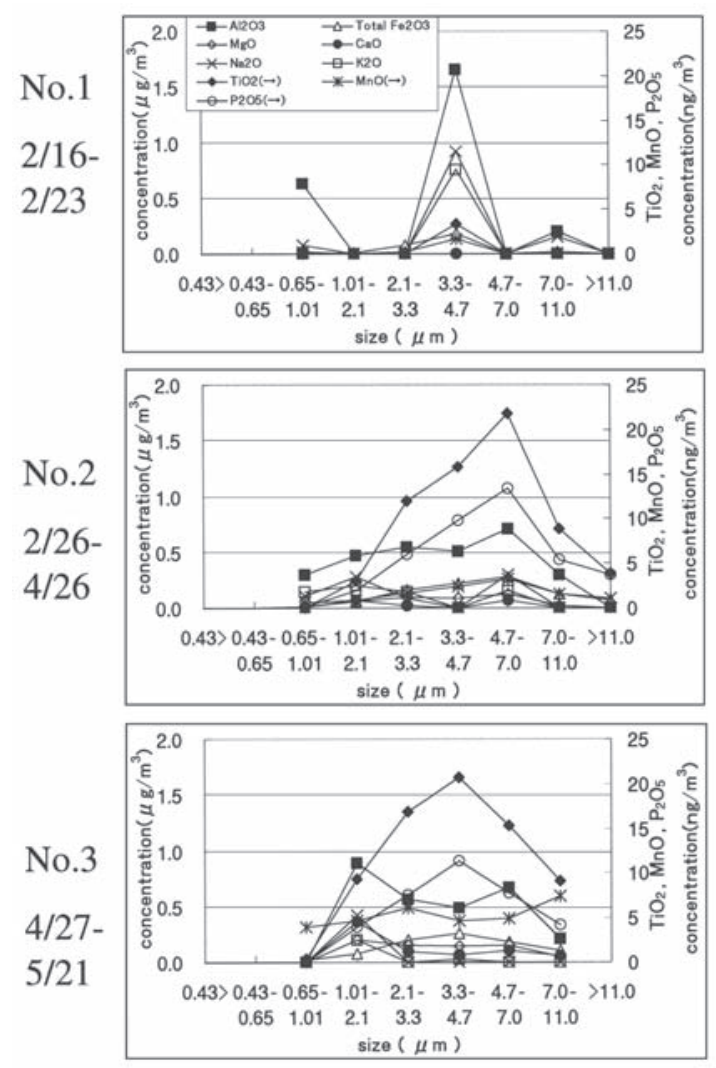

Fig. 8 Example of chemical composition of the water-insoluble fraction in dust samples taken in Tsukuba, 2001. Data for particles less than $0.65 \mu \mathrm{m}$ are eliminated because they are near the blank values. 
Table 4 Mineral composition of dust particles collected in Japan.

\begin{tabular}{|c|c|c|c|c|c|c|c|c|c|c|c|c|c|c|c|c|c|c|c|c|}
\hline & & & & & & & & & elat & ive $\mathrm{i}$ & inte & asit & (ar & bitra & ary 1 & unit) & & & & \\
\hline & & $\mathrm{mir}$ & eral & & & & 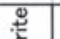 & 8 & 8 & 8 & : & E్ & हैे & E & 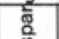 & \& & $\frac{10}{0}$ & $\underline{\xi}$ & 3 & \\
\hline sam & & & & & & & $\frac{0}{5}$ & 胥 & & छે & & $\sum_{\text {c̆ }}^{\circ}$ & & ปั & $\frac{8}{0}$ & \% & $\frac{ㅇ ㅡ ㄹ ~}{\frac{2}{2}}$ & 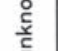 & 동 & sample amount \\
\hline No. & name & start c & late & & stop & date & & & & & & & & & & & & & & (g) \\
\hline 1 & 地 1 & 2 & 16 & - & 2 & 23 & 2 & & 9 & & & & & 9 & 2 & 4 & 1 & 1 & 1 & 0.68126 \\
\hline 2 & 地2 & 2 & 26 & - & 3 & 12 & 2 & ? & 4 & & 4 & & & 12 & & & 1 & 1 & 1 & 1.11049 \\
\hline 3 & 地3 & 3 & 12 & - & 3 & 21 & 2 & & 4 & & 4 & & & 12 & & & 1 & 1 & 1 & 0.97739 \\
\hline 4 & 地4 & 3 & 21 & - & 4 & 2 & 5 & & 11 & & & & & 10 & 3 & 7 & 1 & 1 & 1 & 0.72870 \\
\hline 5 & 地5 & 4 & 2 & - & 4 & 19 & 3 & & 8 & & & & & 11 & 3 & 6 & & 1 & 2 & 1.54563 \\
\hline 6 & 地6 & 4 & 20 & - & 5 & 11 & ง & & 8 & & & & & 8 & & 3 & & 1 & 2 & 1.72366 \\
\hline 7 & 地7 & 5 & 11 & - & 5 & 21 & 4 & & 7 & & & & & 6 & 2 & 4 & 1 & 1 & 2 & 0.96386 \\
\hline 8 & 地8 & 5 & 22 & - & 6 & 1 & 1 & & 5 & & & & & 4 & & 3 & & 2 & 2 & 0.44041 \\
\hline 9 & 地 9 & 6 & 1 & - & 6 & 11 & 2 & & 10 & & & & 1 & 6 & 4 & 4 & & 1 & 2 & 0.64145 \\
\hline 10 & 地11 & 6 & 21 & - & 7 & 2 & 2 & & 11 & & & & & 7 & 2 & 4 & & $<1$ & 2 & 0.82397 \\
\hline 11 & 地13 & 7 & 11 & - & 7 & 23 & 2 & & 7 & & & & $<1$ & 8 & & 5 & & 2 & 2 & 0.72312 \\
\hline \begin{tabular}{|l|}
12 \\
\end{tabular} & 地 15 & 8 & 2 & - & 8 & 13 & 2 & & 6 & & & & & 4 & & 3 & & 1 & 2 & 0.54768 \\
\hline \begin{tabular}{|l|}
13 \\
\end{tabular} & 地17 & 8 & 21 & - & 9 & 3 & 1 & & 7 & & & & & 2 & & 3 & & $<1$ & 2 & 0.60370 \\
\hline \begin{tabular}{|l|}
14 \\
\end{tabular} & 地19 & 9 & 12 & - & 9 & 21 & 1 & & 6 & & & & & 3 & 1 & 1 & & 2 & 2 & 0.39439 \\
\hline \begin{tabular}{|l}
15 \\
\end{tabular} & 地22 & 10 & 11 & - & 10 & 22 & 1 & & 7 & & & & & 5 & 2 & 3 & & 3 & 2 & 0.66824 \\
\hline \begin{tabular}{|l|}
16 \\
\end{tabular} & 地24 & 11 & 2 & - & 11 & 12 & 1 & & 6 & & & & & 3 & 1 & 2 & & 1 & 2 & 0.49392 \\
\hline 17 & 名2 & 3 & 15 & - & 3 & 20 & 4 & & 5 & & & & & 13 & 3 & 6 & 1 & 1 & 2 & 0.61790 \\
\hline 18 & 名5 & 4 & 1 & - & 4 & 7 & 3 & & 7 & & & & & 9 & 4 & 4 & 1 & 3 & 2 & 0.47680 \\
\hline 19 & 名7 & 4 & 12 & - & 4 & 17 & 5 & & 8 & & & & & 9 & 4 & 6 & 1 & 1 & 2 & 0.78250 \\
\hline 20 & 名9 & 4 & 26 & - & 5 & 4 & 3 & & 5 & & & & & 7 & 4 & 4 & 1 & 2 & 2 & 0.49110 \\
\hline 21 & 名11 & 5 & 11 & - & 5 & 19 & 7 & & 13 & & & & & 14 & 6 & 9 & 2 & & 2 & 0.96400 \\
\hline 22 & 名13 & 6 & 1 & - & 6 & 7 & 2 & & 6 & & & & & 8 & 7 & 6 & 1 & $<1$ & 2 & 0.43120 \\
\hline 23 & 名15 & 6 & 16 & - & 6 & 25 & & & 2 & & & & & 2 & 1 & 1 & & 2 & 2 & 0.54260 \\
\hline 24 & 名17 & 7 & 5 & - & 7 & 11 & 2 & & 6 & & & & & 3 & 2 & 2 & 1 & 1 & 2 & 0.40290 \\
\hline 25 & 福1 & 4 & 24 & - & 5 & 7 & 5 & & 5 & & & & & 6 & 3 & 4 & 2 & & 2 & 0.94280 \\
\hline 26 & 福2 & 5 & 7 & - & 5 & 16 & 6 & & 7 & 1 & & & & 5 & 5 & 6 & 4 & & 2 & 0.63640 \\
\hline 27 & 福3 & 5 & 16 & - & 5 & 23 & 5 & & 6 & & & & & 14 & 5 & 8 & 2 & 1 & 1 & 1.44800 \\
\hline 28 & 福4 & 5 & 23 & - & 5 & 30 & 5 & & 5 & 1 & & & & 6 & 5 & 6 & 4 & & 2 & 0.58300 \\
\hline 29 & 福5 & 5 & 30 & - & 6 & 6 & 4 & & 5 & & & & & 5 & 3 & 4 & 3 & 1 & 2 & 0.49190 \\
\hline 30 & 福6 & 6 & 6 & - & 6 & 13 & 6 & & 6 & 1 & & & & 5 & 6 & 7 & 5 & 1 & 2 & 0.55460 \\
\hline 31 & 福7 & 6 & 13 & - & 6 & 20 & 2 & & 1 & 1 & & & & 3 & 5 & 6 & 4 & & 2 & 0.29140 \\
\hline \begin{tabular}{|l|}
32 \\
\end{tabular} & 福9 & 6 & 27 & - & 7 & 4 & 3 & & 3 & 1 & & & & 3 & 5 & 6 & 3 & 1 & 2 & 0.27230 \\
\hline \begin{tabular}{|c|}
33 \\
\end{tabular} & 福11 & 7 & 11 & - & 7 & 19 & & & 1 & & & & & 1 & 1 & 2 & 1 & $<1$ & 2 & 0.21210 \\
\hline \begin{tabular}{|l|}
34 \\
\end{tabular} & 福13 & 7 & 26 & - & 8 & 2 & 2 & & 2 & 1 & & & & 5 & 4 & 7 & 2 & 1 & 2 & 0.33700 \\
\hline 35 & 福15 & 8 & 9 & - & 8 & 23 & 3 & & 2 & 1 & & & & 3 & & 5 & 5 & $<1$ & 2 & 0.60130 \\
\hline
\end{tabular}

During IOP-1, the AN-200 was operated for a much shorter time than usual (for example, usual 20 days decreased to 4-7 days in Tsukuba) in order to collect the dust samples from each dust storm event. However, the shorter collection time led to a small amount of dust collected and inaccurate data for both particle size and chemical analyses. We need a greater amount of dust for one sample, and better sampling (samples need to be collected in a shorter period). Both are contrary to each other. We need at least several mg of sample for chemical analysis in each filter sample. In the usual condition, the average concentration is around $30 \mu \mathrm{g} / \mathrm{m}^{3}$ (average air concentration of each sampling stage is $\left.3-4 \mu \mathrm{g} / \mathrm{m}^{3}\right)$, and 25 days are necessary for the collection of a $4 \mathrm{mg}$ dust sample. During IOP, the air concentration is expected to be larger than usual. Therefore, one week or so is expected to be sufficient for the best observation condition, considering both the sample amount and time resolution of the dust storm event.

The observation results are already shown in the previous chapters. In conclusion, the dust samples were collected in a good resolution. We elucidated that the dust concentrations in China are much higher than in Japan and proportion of larger particles increases in size when a dust event occurred. The largest particles $(>11 \mu \mathrm{m})$ sharply increased, especially in Beijing (Kanai et al., 2002c).

\section{Conclusions}

In order to clarify the variation and characterization of dust particles that originate in the desert area of western China and are transported to Japan, we established a sampling network system and collected aeolian dust under the Japan-China joint project "Studies on origin and transport of aeolian dust and its impact on climate". We started to observe the dust concentration and analyze the dust particles to study their physicochemical properties.

The seasonal variations of dust concentration were observed in Tsukuba, Nagoya, Fukuoka, Naha and Qingdao. It showed a tendency that the aerosol content was high in the spring, and low in the summer. It sometimes became high in Qingdao in the winter.

The aerosol size distribution showed two peaks. One 
peak at around $0.5 \mu \mathrm{m}$ corresponds to particles of anthropogenic origin. The other peak at around $4-5 \mu \mathrm{m}$ corresponds to mineral dust from soil. The coarser particles increased when a dust event occurred.

The IOP-1 program was started in April 2002. The dust concentration during that period was high in China, especially in Beijing. The average dust concentration during a dust storm event seems to be in the order of Beijing $>$ Qingdao $>$ Hefei and Beijing $>$ Fukuoka $>$ Nagoya $>$ Tsukuba $>$ Naha. Usual dust concentration in Japan seemed to be almost the same. This might suggest that the separation of dust was achieved in China and dust particles were transported to Japan as a nearly homogeneous mass.

The main chemical components of the water-soluble fraction are supposed to be $\left(\mathrm{NH}_{4}\right)_{2} \mathrm{SO}_{4}$ in finer particles and $\mathrm{Ca}\left(\mathrm{NO}_{3}\right)_{2}, \mathrm{CaCl}_{2}, \mathrm{NaNO}_{3}$ and $\mathrm{NaCl}$ in coarser particles. Aluminum content in the water-insoluble fraction was high in coarser particles, and this confirmed that they consisted of mineral component.

This study was partly supported by Special Coordination Funds of the Ministry of Education, Culture, Sports, Science and Technology of Japan.

\section{References}

Decesari, S., Facchini, M.C., Matta, E., Lettini, F., Miccea, M., Fuzzi, S., Tagliavini, E. and Putaud, J-.P. (2001) Chemical features and seasonal variation of fine aerosol water-soluble organic compounds in the Po Valley, Italy. Atmospheric Environment, 35, 36913699.

Inoue, K. and Mizota, C. (1988) Eolian origin of 2:1 layer silicates and fine quartz in andosols and red-yellow soils developed on limestones and basalts. Nendo Kagaku, 28, 30-47.

Kamioka, H. and Kanai, Y. (2002) Water-soluble ion species in Aeolian dust collected by a low-volume air sampler in Tsukuba, Ibaraki. $49^{\text {th }}$ annual meeting of the Geochemical Society of Japan, Kagoshima, 2002.9, p.136. (abstract)

Kanai, Y. (2001) Outline of the project "Studies on origin and transport of aeolian dust and its impact on climate", and quaternary and geochemical studies on aerosol. Chishitsu News, 565, 11-23.

Kanai, Y., Ohta, A., Kamioka, H., Terashima, S., Matsuhisa, Y., Shimizu, H., Takahashi, Y., Kai, K., Xu, B., Hayashi, M. and Zhang, R. (2002a) Preliminary study on the grain-size distribution and concentration of aeolian dust collected in Japan. J. Arid Land Studies, 11, 307-314.

Kanai, Y., Ohta, A., Kamioka, H., Terashima, S., Matsuhisa, Y., Shimizu, H., Takahashi, Y., Kai, K., Xu, B., Hayashi, M. and Zhang, R. (2002b) Preliminary study on the physicochemical properties of aeolian dust collected in Japan and east China. $1^{\text {st }}$ ADEC workshop, Tokyo, 2001.1, p.19. (abstract)

Kanai, Y., Ohta, A., Kamioka, H., Terashima, S., Imai, N., Matsuhisa, Y., Shimizu, H., Takahashi, Y., Kai, K., Xu, B., Hayashi, M. and Zhang, R. (2002c) Observation of transported aeolian dust in east China and Japan. $49^{\text {th }}$ annual meeting of the Geochemical Society of Japan, Kagoshima, 2002.9, p.139. (abstract)

Mikami, M., Abe, O, Du, M., Chiba, O., Fujita, K., Hayashi, M., Iwasaka, Y., Kai, K., Masuda, K., Nagai, T., Ootomo, T., Suzuki, J., Uchiyama, A., Yabuki, S., Yamada, Y., Yasui, M., Shi, G., Zhang, X., Shen, Z., Wei, W. and Zhou, J. (2002) The impact of Aeolian dust on climate: Shino-Japan cooperative project ADEC. J. Arid Land Studies, 11, 211-222.

Mizota, C. and Inoue, K. (1988) Oxygen isotope composition of eolian quartz in soils and sediments - its significance as a tracer of eolian components -. Nendo Kagaku, 28, 38-54.

National Institute for Environmental Studies (2001) International cooperation research on the methodological development for urban aerosol characteristics in China. Report of Special Research from the National Institute for Environmental Studies, Japan. SR-432001, 59p.

Nishikawa, M., Kanamori, S., Kanamori, N. and Mizoguchi, T. (1987) Chemical composition and size distribution of water soluble and insoluble contents in atmospheric aerosol. J. Aerosol Research of Japan, 2, 294-303.

Ohta, A., Terashima, S., Kanai, Y., Kamioka, H., Imai, N., Matsuhisa, Y., Shimizu, H., Takahashi, Y., Kai, K., Hayashi, M. and Zhang, R. (2003) The grain size distribution of chemical composition of water-insoluble components in Aeolian dust collected in Japan in spring of 2002. to be submitted.

Spanos, Th., Simeonov, V. and Andreev, G. (2002) Environmetric modeling of emission sources for dry and wet precipitation from urban area. Talanta, 58, 367-375.

Streets, D.G., Gupta, S., Waldhoff, S.T., Wang, M.Q., Bond, T.C. and Yiyun, B. (2001) Black carbon emissions in China. Atmospheric Environment, 35, 42814296.

Yabuki, S., Kanayama, S., Fu, F., Honda, M., Yanagisawa, F., Wei, W., Zheng, F., Liu, M., Shen, Z. and Liu, L. (2002) Physical and chemical characteristics of aeolian dust collected over Asian dust source regions in China - comparison with atmospheric aerosols in an urban area at Wako, Japan. J. Arid Land Studies, 11, 273-289.

Zhang, X., Arimoto, R. and An, Z. (1997) Dust emission from Chinese desert sources linked to variations in atmospheric circulation. J. Geophys. Res., 102, 2804128047.

Zhang, D. and Iwasaka, Y. (1998) Morphology and chemi- 
cal composition of individual dust particles collected over Wakasa Bay, Japan. J. Aerosol Science, 29, $217-$ 218 .

Received August 4, 2003

Accepted September 25, 2003

Appendix 1a Aeolian dust concentrations in (1) Tsukuba and (2) Nagoya in 2001- 2002 by a high-volume air sampler (HV-1000F). The times in the appendix tables are shown as the local time.

(1) Tsukuba

\begin{tabular}{|c|c|c|c|c|c|}
\hline No. & start & & stop & & dust \\
\hline & date & time & date & time & $\mu \mathrm{g} / \mathrm{m}^{3}$ \\
\hline 1 & 2001.2 .16 & $15: 55$ & $\sim 2001.2 .23$ & $14: 17$ & 68.25 \\
\hline 2 & 2001.2.26 & $17: 05$ & $\sim 2001.3 .12$ & $10: 25$ & 56.20 \\
\hline 3 & 2001. 3. 12 & $11: 35$ & $\sim 2001.3 .21$ & $17: 17$ & 73.67 \\
\hline 4 & 2001.3.21 & $17: 21$ & $\sim 2001.4 .2$ & $14: 12$ & 50.84 \\
\hline 5 & 2001. 4. 2 & $14: 43$ & $\sim 2001.4 .19$ & $17: 43$ & 64.18 \\
\hline 6 & 2001. 4. 20 & $17: 55$ & $\sim 2001.5 .11$ & $18: 19$ & 56.96 \\
\hline 7 & 2001. 5. 11 & $18: 23$ & $\sim 2001.5 .21$ & $15: 47$ & 67.66 \\
\hline 8 & 2001.5 .22 & $18: 04$ & $\sim 2001.6 .1$ & $16: 12$ & 30.82 \\
\hline 9 & 2001.6.1 & $16: 15$ & $\sim 2001.6 .11$ & $15: 39$ & 44. 66 \\
\hline 10 & 2001.6. 11 & $15: 42$ & $\sim 2001.6 .21$ & $14: 55$ & 26. 37 \\
\hline 11 & 2001.6.21 & $15: 03$ & $\sim 2001.7 .2$ & $11: 35$ & 52.71 \\
\hline 12 & 2001. 7.2 & $18: 42$ & $\sim 2001.7 .11$ & $16: 39$ & 46.84 \\
\hline 13 & 2001.7 .11 & $16: 41$ & $\sim 2001.7 .23$ & $18: 50$ & 41.54 \\
\hline 14 & 2001. 7.23 & $18: 53$ & $\sim 2001.8 .2$ & $9: 03$ & 44.83 \\
\hline 15 & 2001.8 .2 & $16: 42$ & $\sim 2001.8 .13$ & $10: 53$ & 35.36 \\
\hline 16 & 2001. 8. 13 & $10: 57$ & $\sim 2001.8 .21$ & $9: 58$ & 32.52 \\
\hline 17 & 2001.8.21 & $17: 17$ & $\sim 2001.9 .3$ & $9: 10$ & 33.39 \\
\hline 18 & 2001.9. 3 & $9: 14$ & $\sim 2001.9 .12$ & $10: 25$ & 36.11 \\
\hline 19 & 2001.9. 12 & $10: 27$ & $\sim 2001.9 .21$ & $10: 20$ & 30.45 \\
\hline 20 & 2001.9.21 & $10: 25$ & $\sim 2001.10 .1$ & $10: 45$ & 32.95 \\
\hline 21 & 2001. 10. 3 & $15: 14$ & $\sim 2001.10 .11$ & $11: 00$ & 23.51 \\
\hline 22 & 2001.10 .11 & $11: 04$ & $\sim 2001.10 .22$ & $13: 20$ & 43.17 \\
\hline 23 & 2001.10 .22 & $13: 24$ & $\sim 2001.11 .2$ & $10: 07$ & 46. 30 \\
\hline 24 & 2001. 11. 2 & $10: 11$ & $\sim 2001.11 .12$ & $10: 00$ & 34.33 \\
\hline 25 & 2001.11 .12 & $10: 05$ & $\sim 2001.11 .21$ & $13: 29$ & 43.83 \\
\hline 26 & 2001.11 .21 & $13: 35$ & $\sim 2001.11 .30$ & $10: 05$ & 67.10 \\
\hline 27 & 2001.12 .3 & $15: 07$ & $\sim 2001.12 .11$ & $14: 11$ & 39.29 \\
\hline 28 & 2001.12 .11 & $14: 14$ & $\sim 2001.12 .20$ & $13: 41$ & 40.83 \\
\hline 29 & 2001. 12. 20 & $13: 45$ & $\sim 2001.12 .31$ & $14: 00$ & 40.13 \\
\hline 30 & 2001. 12.31 & $14: 04$ & $\sim 2002.1 .11$ & $10: 48$ & 35.97 \\
\hline 31 & 2002.1 .11 & $10: 55$ & $\sim 2002.1 .21$ & $9: 03$ & 46.61 \\
\hline 32 & 2002.1.21 & $14: 16$ & $\sim 2002.2 .1$ & $13: 35$ & 25.56 \\
\hline 33 & 2002.2.1 & $13: 28$ & $\sim 2002.2 .12$ & $10: 08$ & 50.38 \\
\hline 34 & 2002.2. 12 & $10: 10$ & $\sim 2002.2 .21$ & $14: 35$ & 55.52 \\
\hline 35 & 2002.2.21 & $14: 38$ & $\sim 2002.3 .1$ & $10: 54$ & 68.38 \\
\hline 36 & 2002. 3.1 & $10: 57$ & $\sim 2002.3 .11$ & $10: 18$ & 68.58 \\
\hline 37 & 2002.3.11 & $10: 28$ & $\sim 2002.3 .20$ & $10: 15$ & 82.89 \\
\hline 38 & 2002. 3. 20 & $10: 20$ & $\sim 2002.3 .26$ & $10: 17$ & 127. 37 \\
\hline 39 & 2002. 3. 26 & $10: 21$ & $\sim 2002.4 .1$ & $13: 09$ & 53.21 \\
\hline 40 & 2002. 4. 1 & $13: 10$ & $\sim 2002.4 .6$ & $13: 35$ & 51.02 \\
\hline 41 & 2002.4 .6 & $13: 37$ & $\sim 2002.4 .12$ & $13: 36$ & 152. 36 \\
\hline 42 & 2002. 4. 12 & $13: 38$ & $\sim 2002.4 .17$ & $10: 16$ & 94.29 \\
\hline 43 & 2002.4 .17 & $10: 19$ & $\sim 2002.4 .24$ & $9: 22$ & 81.93 \\
\hline 44 & 2002. 4.24 & $9: 26$ & $\sim 2002.5 .8$ & $9: 34$ & 38.69 \\
\hline 45 & & & & & \\
\hline 46 & & & & & \\
\hline 47 & & & & & \\
\hline 48 & & & & & \\
\hline 49 & & & & & \\
\hline 50 & & & & & \\
\hline 51 & & & & & \\
\hline
\end{tabular}

(2) Nagoya

\begin{tabular}{|c|c|c|c|c|}
\hline \multicolumn{2}{|c|}{ start } & \multicolumn{2}{|c|}{ stop } & dust \\
\hline date & time & date & time & $\mu \mathrm{g} / \mathrm{m}^{3}$ \\
\hline 2001.3.15 & $14: 26$ & $\sim 2001.3 .20$ & $17: 00$ & 83.97 \\
\hline 2001.3. 26 & $12: 30$ & $\sim 2001.4 .1$ & $15: 35$ & 49.74 \\
\hline 2001.4 .1 & $15: 40$ & $\sim 2001.4 .7$ & $13: 56$ & 55.82 \\
\hline 2001.4 .7 & $14: 00$ & $\sim 2001.4 .12$ & $15: 51$ & 85.40 \\
\hline 2001.4.12 & $15: 52$ & $\sim 2001.4 .17$ & $18: 32$ & 106. 34 \\
\hline 2001. 4.17 & $18: 37$ & $\sim 2001.4 .24$ & $12: 10$ & 85.19 \\
\hline 2001.4 .26 & $9: 35$ & $\sim 2001.5 .4$ & $13: 40$ & 41.75 \\
\hline 2001.5 .4 & $13: 40$ & $\sim 2001.5 .11$ & $15: 20$ & 37.66 \\
\hline 2001.5 .11 & $15: 23$ & $\sim 2001.5 .19$ & $12: 45$ & 84.82 \\
\hline 2001. 5.23 & $13: 15$ & $\sim 2001.5 .31$ & $12: 10$ & 39.39 \\
\hline 2001.6 .1 & $10: 55$ & $\sim 2001.6 .7$ & $16: 00$ & 48.19 \\
\hline 2001.6. 7 & $16: 05$ & $\sim 2001.6 .14$ & $16: 30$ & 54.21 \\
\hline 2001.6. 16 & $11: 55$ & $\sim 2001.6 .25$ & $15: 05$ & 41.26 \\
\hline 2001. 6.26 & $18: 15$ & $\sim 2001.7 .3$ & $11: 45$ & 47. 72 \\
\hline 2001. 7.5 & $10: 05$ & $\sim 2001.7 .11$ & $11: 30$ & 39.64 \\
\hline 2001.7. 11 & $12: 40$ & $\sim 2001.7 .19$ & $10: 05$ & 27.82 \\
\hline 2002.8 .18 & $14: 50$ & $\sim 2002.8 .22$ & $15: 00$ & 31.98 \\
\hline 2002. 8. 23 & $12: 30$ & $\sim 2002.8 .29$ & $15: 50$ & 33.65 \\
\hline 2002.8.29 & $15: 55$ & $\sim 2002.9 .4$ & $18: 03$ & 37.20 \\
\hline 2002.9. 4 & $18: 17$ & $\sim 2002.9 .11$ & $15: 55$ & 32.30 \\
\hline 2002.9.11 & $16: 27$ & $\sim 2002.9 .17$ & $12: 53$ & 20.48 \\
\hline 2002.9.19 & $12: 56$ & $\sim 2002.9 .26$ & $12: 38$ & 36.61 \\
\hline 2002.9.29 & $15: 35$ & $\sim 2002.10 .8$ & $13: 16$ & 37.18 \\
\hline 2002. 10.8 & $13: 45$ & $\sim 2002.10 .17$ & $15: 55$ & 40.35 \\
\hline 2002.10 .17 & $15: 57$ & $\sim 2002.10 .25$ & $13: 52$ & 33.63 \\
\hline 2002.10 .25 & $13: 54$ & $\sim 2002.10 .31$ & $15: 47$ & 44. 16 \\
\hline 2002.10 .31 & $15: 50$ & $\sim 2002.11 .7$ & $14: 34$ & 39.16 \\
\hline 2002.11 .7 & $14: 35$ & $\sim 2002.11 .14$ & $14: 39$ & 35.87 \\
\hline 2002.11 .14 & $14: 42$ & $\sim 2002.11 .21$ & $13: 20$ & 36.36 \\
\hline 2002.11 .21 & $13: 22$ & $\sim 2002.11 .28$ & $14: 15$ & 44.57 \\
\hline 2002.11 .28 & $14: 15$ & $\sim 2002.12 .5$ & $14: 04$ & 41.50 \\
\hline 2002.12 .5 & $13: 20$ & $\sim 2002.12 .12$ & $13: 40$ & 24.03 \\
\hline 2002.12 .12 & $13: 40$ & $\sim 2002.12 .19$ & $15: 15$ & 28.21 \\
\hline 2002.12 .19 & $15: 20$ & $\sim 2002.12 .26$ & $12: 45$ & 27.66 \\
\hline 2002.12 .26 & $12: 45$ & $\sim 2002.1 .8$ & $16: 10$ & 25.64 \\
\hline 2002.1 .8 & $16: 10$ & $\sim 2002.1 .16$ & $15: 40$ & 54.21 \\
\hline 2002.1. 16 & $15: 45$ & $\sim 2002.1 .22$ & $12: 30$ & 45.21 \\
\hline 2002.2. 1 & $15: 45$ & $\sim 2002.2 .8$ & $16: 10$ & 28.16 \\
\hline 2002.2 .8 & $19: 31$ & $\sim 2002.2 .15$ & $13: 25$ & 24.07 \\
\hline 2002.2. 15 & $19: 27$ & $\sim 2002.2 .25$ & $12: 05$ & 35.67 \\
\hline 2002.2.25 & $12: 05$ & $\sim 2002.3 .4$ & $12: 50$ & 48.41 \\
\hline 2002. 3.4 & $12: 56$ & $\sim 2002.3 .11$ & $15: 28$ & 42.83 \\
\hline 2002.3. 11 & $17: 20$ & $\sim 2002.3 .18$ & $12: 41$ & 45.48 \\
\hline 2002. 3. 18 & $12: 43$ & $\sim 2002.3 .27$ & $15: 00$ & 94.39 \\
\hline 2002. 3. 28 & $15: 40$ & $\sim 2002.4 .2$ & $12: 17$ & 49.56 \\
\hline 2002. 4. 2 & $17: 59$ & $\sim 2002.4 .8$ & $8: 56$ & 69.70 \\
\hline 2002.4 .8 & $10: 37$ & $\sim 2002.4 .10$ & $15: 52$ & 196. 73 \\
\hline 2002.4 .10 & $16: 35$ & $\sim 2002.4 .12$ & $12: 36$ & 131.84 \\
\hline 2002. 4. 12 & $12: 36$ & $\sim 2002.4 .16$ & $15: 59$ & 94.46 \\
\hline 2002.4 .16 & $15: 59$ & $\sim 2002.4 .22$ & $10: 59$ & 73.94 \\
\hline 2002.4 .22 & $17: 26$ & $\sim 2002.4 .25$ & $11: 13$ & 74.76 \\
\hline
\end{tabular}


Appendix 1b Aeolian dust concentrations in (3) Fukuoka and (4) Naha in 2001-2002 by a high-volume air sampler (HV-1000F).

(3) Fukuoka

\begin{tabular}{|c|c|c|c|c|c|}
\hline No. & start & & stop & & dust \\
\hline & date & time & date & time & $\mu \mathrm{g} / \mathrm{m}^{3}$ \\
\hline 1 & 2001.4 .24 & $11: 40$ & $\sim 2001.5 .7$ & $16: 41$ & 70.78 \\
\hline 2 & 2001. 5.7 & $17: 14$ & $\sim 2001.5 .16$ & $10: 41$ & 50.64 \\
\hline 3 & 2001. 5. 16 & $11: 41$ & $\sim 2001.5 .23$ & $11: 56$ & 143.42 \\
\hline 4 & 2001. 5. 23 & $12: 22$ & $\sim 2001.5 .30$ & $18: 58$ & 55.64 \\
\hline 5 & 2001. 5. 30 & $19: 19$ & $\sim 2001.6 .6$ & $13: 29$ & 50.56 \\
\hline 6 & 2001.6 .6 & $13: 42$ & $\sim 2001.6 .13$ & $16: 46$ & 54.04 \\
\hline 7 & 2001. 6.13 & $16: 59$ & $\sim 2001.6 .20$ & $13: 42$ & 29.48 \\
\hline 8 & 2001.6 .20 & $13: 55$ & $\sim 2001.6 .27$ & $10: 37$ & 20.51 \\
\hline 9 & 2001.6 .27 & $18: 58$ & $\sim 2001.7 .4$ & $12: 26$ & 28.11 \\
\hline 10 & 2001. 7.4 & $14: 24$ & $\sim 2001.7 .11$ & $11: 10$ & 29.52 \\
\hline 11 & 2001.7.11 & $14: 18$ & $\sim 2001.7 .19$ & $9: 14$ & 18.91 \\
\hline 12 & 2001.7. 19 & $9: 30$ & $\sim 2001.7 .26$ & $11: 00$ & 26.35 \\
\hline 13 & 2001.7 .26 & $11: 20$ & $\sim 2001.8 .2$ & $13: 32$ & 33.01 \\
\hline 14 & 2001.8 .2 & $13: 55$ & $\sim 2001.8 .9$ & $10: 00$ & 35.99 \\
\hline 15 & 2001.8 .9 & $11: 25$ & $\sim 2001.8 .23$ & $11: 31$ & 59.15 \\
\hline 16 & 2001.8. 24 & $11: 53$ & $\sim 2001.8 .31$ & $17: 23$ & 37.17 \\
\hline 17 & 2001. 8. 31 & $18: 09$ & $\sim 2001.9 .7$ & $10: 40$ & 21.05 \\
\hline 18 & 2001. 9.7 & $16: 20$ & $\sim 2001.9 .14$ & $10: 03$ & 32.51 \\
\hline 19 & 2001.9. 14 & $20: 14$ & $\sim 2001.9 .21$ & $9: 21$ & 30.50 \\
\hline 20 & 2001. 9.21 & $18: 24$ & $\sim 2001.9 .28$ & $10: 19$ & 39.19 \\
\hline 21 & 2001.9. 28 & $14: 11$ & $\sim 2001.10 .5$ & $11: 32$ & 33.26 \\
\hline 22 & 2001. 10. 5 & $14: 33$ & $\sim 2001.10 .12$ & $10: 28$ & 49.17 \\
\hline 23 & 2001.10 .13 & $15: 35$ & $\sim 2001.10 .19$ & $10: 25$ & 33.49 \\
\hline 24 & 2001.10 .19 & $13: 56$ & $\sim 2001.10 .26$ & $11: 51$ & 31.12 \\
\hline 25 & 2001.10 .26 & $14: 37$ & $\sim 2001.11 .2$ & $9: 15$ & 45.08 \\
\hline 26 & 2001.11 .2 & $15: 00$ & 2001.11 .9 & $10: 04$ & 15. 78 \\
\hline 27 & 2001.11.9 & $13: 55$ & 2001.11 .16 & $12: 03$ & 28.37 \\
\hline 28 & 2001.11 .26 & $14: 25$ & 2001.12 .3 & $11: 00$ & 29.51 \\
\hline 29 & 2001.12 .4 & $14: 45$ & 2001.12 .14 & $13: 25$ & 34.30 \\
\hline 30 & 2001.12 .17 & $15: 57$ & 2001.12 .27 & $13: 05$ & 37.76 \\
\hline 31 & 2001. 12. 28 & $17: 27$ & $\sim 2002.1 .7$ & $13: 45$ & 51. 15 \\
\hline 32 & 2002.1 .11 & $9: 25$ & $\sim 2002.1 .21$ & $9: 45$ & 43.32 \\
\hline 33 & 2002.1.21 & $12: 50$ & $\sim 2002.1 .31$ & $13: 34$ & 34.52 \\
\hline 34 & 2002.2.1 & $16: 00$ & $\sim 2002.2 .12$ & $10: 42$ & 50.43 \\
\hline 35 & 2002.2.14 & $10: 38$ & $\sim 2002.2 .21$ & $14: 17$ & 43.52 \\
\hline 36 & 2002.2.21 & $15: 40$ & $\sim 2002.3 .1$ & $10: 09$ & 49.43 \\
\hline 37 & 2002. 3. 1 & $10: 58$ & $\sim 2002.3 .11$ & $10: 24$ & 86.52 \\
\hline 38 & 2002.3.11 & $10: 44$ & $\sim 2002.3 .22$ & $11: 20$ & 146. 44 \\
\hline 39 & 2002. 3. 22 & $16: 16$ & $\sim 2002.4 .1$ & $12: 55$ & 100.86 \\
\hline 40 & 2002.4 .1 & $13: 50$ & $\sim 2002.4 .5$ & $18: 59$ & 74.78 \\
\hline 41 & 2002.4 .6 & $9: 15$ & $\sim 2002.4 .11$ & $15: 36$ & 244.54 \\
\hline 42 & 2002.4 .12 & $11: 34$ & $\sim 2002.4 .16$ & $12: 39$ & 110.27 \\
\hline 43 & 2002.4 .17 & $10: 37$ & $\sim 2002.4 .25$ & $9: 03$ & 65.85 \\
\hline 44 & 2002.4 .25 & $11: 05$ & $\sim 2002.5 .1$ & $17: 01$ & 41.69 \\
\hline 45 & 2002.5 .1 & $17: 42$ & $\sim 2002.5 .10$ & $21: 14$ & 24.66 \\
\hline
\end{tabular}

(4) Naha

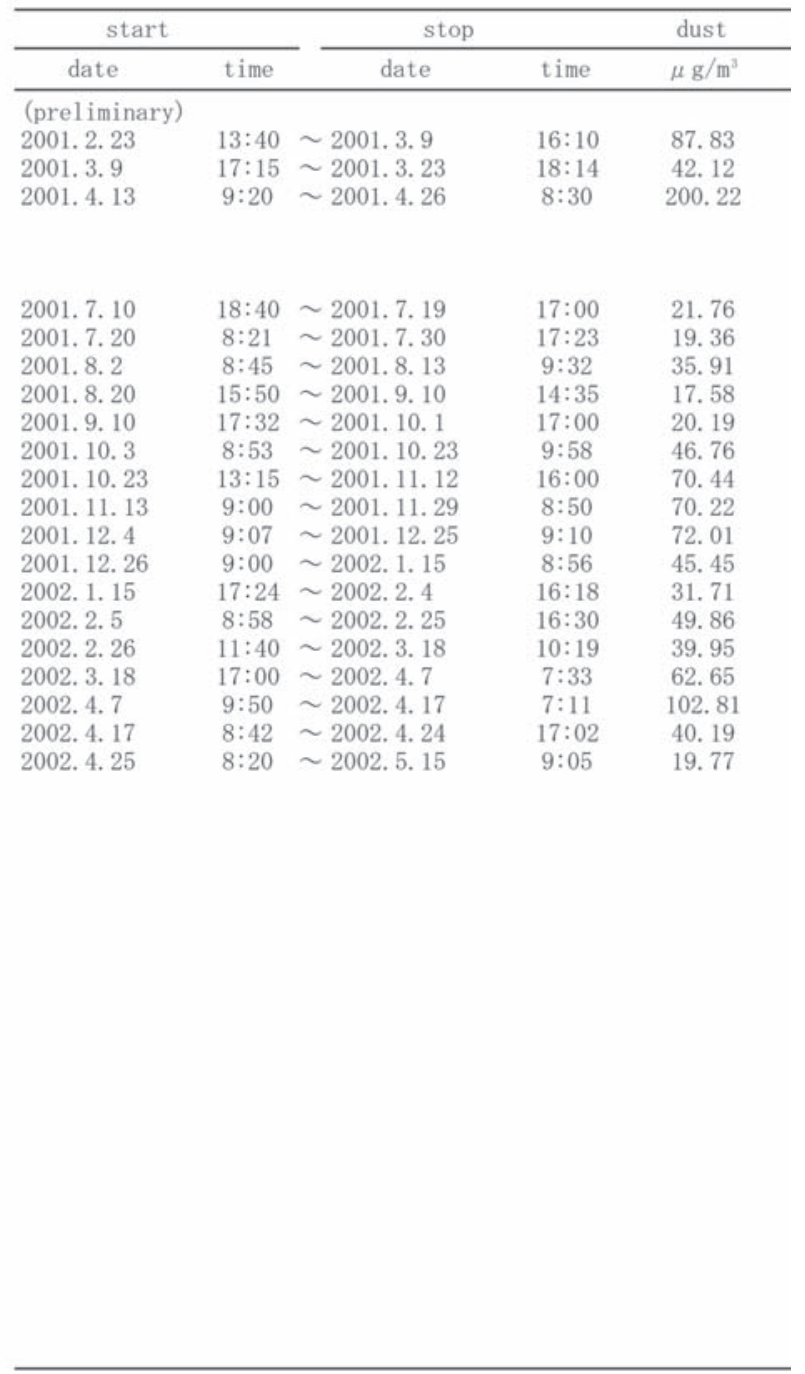

Appendix 1c Aeolian dust concentrations in (5) Qingdao, (6) Beijing and (7) Hefei in 2001-2002 by a high-volume air sampler (HV-1000F).

(5) Qingdao

\begin{tabular}{|c|c|c|c|c|c|}
\hline No. & \multicolumn{2}{|c|}{ start } & \multicolumn{2}{|l|}{ stop } & \multirow{2}{*}{$\begin{array}{l}\text { dust } \\
\mu \mathrm{g} / \mathrm{m}^{3}\end{array}$} \\
\hline & date & time & date & time & \\
\hline 1 & 2001.5 .1 & $8: 30$ & $\sim 2001.5 .6$ & $9: 00$ & 27.17 \\
\hline 2 & 2001.5 .6 & $9: 00$ & $\sim 2001.5 .11$ & $8: 20$ & 97.29 \\
\hline 3 & 2001.5 .12 & $8: 30$ & $\sim 2001.5 .15$ & $7: 55$ & 79.51 \\
\hline 4 & 2001.5 .22 & $10: 00$ & $\sim 2001.5 .24$ & $12: 20$ & 117.46 \\
\hline 5 & 2001.6 .6 & $9: 45$ & $\sim 2001.6 .11$ & $10: 00$ & 76.94 \\
\hline 6 & 2001.6 .14 & $10: 30$ & $\sim 2001.6 .19$ & $10: 00$ & 40.89 \\
\hline 7 & 2001.6 .19 & $10: 04$ & $\sim 2001.6 .24$ & $8: 50$ & 88.33 \\
\hline 8 & 2001. 6. 25 & $8: 30$ & $\sim 2001.6 .29$ & $10: 00$ & 55.79 \\
\hline 9 & 2001.7 .2 & $14: 35$ & $\sim 2001.7 .6$ & $14: 35$ & 162.71 \\
\hline 10 & 2001.7 .7 & $8: 20$ & $\sim 2001.7 .11$ & $8: 20$ & 69.62 \\
\hline 11 & 2001.7 .13 & $11: 20$ & $\sim 2001.7 .17$ & $11: 02$ & 105.80 \\
\hline 12 & 2001.7 .25 & $10: 10$ & $\sim 2001.7 .29$ & $10: 10$ & 102.95 \\
\hline 13 & 2001. 8.2 & $9: 10$ & $\sim 2001.8 .6$ & $9: 18$ & 37.36 \\
\hline 14 & 2001.8 .7 & $10: 10$ & $\sim 2001.8 .11$ & $10: 50$ & 147. 32 \\
\hline 15 & 2001. 8. 17 & $10: 20$ & $\sim 2001.8 .21$ & $16: 35$ & 51.27 \\
\hline 16 & 2001.8. 24 & $9: 20$ & $\sim 2001.8 .29$ & $9: 20$ & 119.26 \\
\hline
\end{tabular}

(6) Beijing

\begin{tabular}{|c|c|c|c|c|}
\hline \multicolumn{2}{|c|}{ start } & \multicolumn{2}{|c|}{ stop } & \multirow{2}{*}{$\frac{\text { dust }}{\mu \mathrm{g} / \mathrm{m}^{3}}$} \\
\hline date & time & date & time & \\
\hline 2002.2.27 & $10: 00$ & $\sim 2002.3 .1$ & $10: 00$ & 319.06 \\
\hline 2002.3.1 & $10: 00$ & $\sim 2002.3 .4$ & $10: 00$ & 325.79 \\
\hline 2002. 3. 19 & $10: 00$ & $\sim 2002.3 .20$ & $10: 45$ & 367.04 \\
\hline 2002. 3. 20 & $10: 45$ & $\sim 2002.3 .20$ & $15: 30$ & 11642.26 \\
\hline 2002.3.20 & $15: 40$ & $\sim 2002.3 .20$ & $21: 00$ & 3682.64 \\
\hline 2002. 3. 20 & $21: 00$ & $\sim 2002.3 .21$ & $10: 00$ & 3045.69 \\
\hline 2002. 3. 21 & $10: 00$ & $\sim 2002.3 .22$ & $10: 00$ & 1487.41 \\
\hline 2002. 3. 22 & $10: 00$ & $\sim 2002.3 .23$ & $10: 00$ & 823.34 \\
\hline 2002.4 .8 & $9: 00$ & $\sim 2002.4 .8$ & $12: 00$ & 3309.43 \\
\hline 2002. 4.8 & $13: 00$ & $\sim 2002.4 .8$ & $21: 00$ & 3014.35 \\
\hline 2002. 4. 11 & $18: 10$ & $\sim 2002.4 .11$ & $20: 20$ & 3904.25 \\
\hline 2002. 4.14 & $13: 30$ & $\sim 2002.4 .15$ & $9: 00$ & 1196.87 \\
\hline 2002. 4. 15 & $15: 50$ & $\sim 2002.4 .16$ & $9: 00$ & 1061.95 \\
\hline 2002. 4. 16 & $9: 05$ & $\sim 2002.4 .16$ & $15: 50$ & 1955.44 \\
\hline 2002. 4. 16 & $15: 50$ & $\sim 2002.4 .16$ & $22: 20$ & 1539.05 \\
\hline 2002. 4. 16 & $22: 30$ & $\sim 2002.4 .17$ & $10: 00$ & 350.27 \\
\hline
\end{tabular}


Appendix 1c Continued.

(5) Qingdao

\begin{tabular}{|c|c|c|c|c|c|}
\hline No. & start & & stop & & dust \\
\hline & date & time & date & time & $\mu \mathrm{g} / \mathrm{m}^{3}$ \\
\hline 17 & 2001.9. 4 & $10: 24$ & $\sim 2001.9 .8$ & $10: 24$ & 100.09 \\
\hline 18 & 2001.9. 13 & $10: 30$ & $\sim 2001.9 .17$ & $10: 30$ & 65.76 \\
\hline 19 & 2001. 9.20 & $13: 25$ & $\sim 2001.9 .25$ & $13: 25$ & 96.87 \\
\hline 20 & 2001. 10. 3 & $9: 46$ & $\sim 2001.10 .7$ & $9: 46$ & 71.20 \\
\hline 21 & 2001. 10.25 & $14: 30$ & $\sim 2001.10 .29$ & $15: 40$ & 200.84 \\
\hline 22 & 2001. 11. 12 & $9: 15$ & $\sim 2001.11 .16$ & $9: 15$ & 103. 66 \\
\hline 23 & 2001. 11.21 & $10: 30$ & $\sim 2001.11 .26$ & $15: 25$ & 147. 11 \\
\hline 24 & 2001.12 .7 & $14: 00$ & $\sim 2001.12 .12$ & $14: 00$ & 245.72 \\
\hline 25 & 2001. 12. 24 & $9: 40$ & $\sim 2001.12 .27$ & $9: 45$ & 220.75 \\
\hline 26 & 2002.1 .5 & $11: 30$ & $\sim 2002.1 .8$ & $14: 07$ & 229.10 \\
\hline 27 & 2002.1 .13 & $10: 55$ & $\sim 2002.1 .14$ & $11: 30$ & 166.13 \\
\hline 28 & 2002. 1. 21 & $10: 30$ & $\sim 2002.1 .24$ & $10: 45$ & 152.71 \\
\hline 29 & 2002.2. 3 & $12: 25$ & $\sim 2002.2 .6$ & $10: 48$ & 172.69 \\
\hline 30 & 2002.2. 16 & $15: 30$ & $\sim 2002.2 .20$ & $15: 30$ & 153.82 \\
\hline 31 & 2002.2. 25 & $8: 30$ & $\sim 2002.2 .28$ & $17: 55$ & 289.43 \\
\hline 32 & 2002.3.2 & $15: 20$ & $\sim 2002.3 .5$ & $9: 14$ & 172.03 \\
\hline 33 & 2002.3. 15 & $11: 05$ & $\sim 2002.3 .19$ & $10: 55$ & 488.00 \\
\hline 34 & 2002.3. 21 & $10: 55$ & $\sim 2002.3 .23$ & $10: 15$ & 721.39 \\
\hline 35 & 2002. 4.1 & $16: 30$ & $\sim 2002.4 .4$ & $15: 30$ & 93.81 \\
\hline 36 & 2002.4 .9 & $10: 20$ & $\sim 2002.4 .13$ & $15: 38$ & 336.87 \\
\hline 37 & 2002.4 .15 & $13: 30$ & $\sim 2002.4 .19$ & $16: 30$ & 268.72 \\
\hline
\end{tabular}

(6) Beijing

\begin{tabular}{|c|c|c|c|c|}
\hline \multicolumn{2}{|c|}{ start } & \multicolumn{2}{|c|}{ stop } & \multirow{2}{*}{$\frac{\text { dust }}{\mu \mathrm{g} / \mathrm{m}^{3}}$} \\
\hline date & time & date & time & \\
\hline 2002.4 .17 & $10: 00$ & $\sim 2002.4 .18$ & $10: 00$ & 500.59 \\
\hline 2002. 4. 18 & $10: 00$ & $\sim 2002.4 .19$ & $10: 00$ & 528. 33 \\
\hline 2002.4 .21 & $9: 40$ & $\sim 2002.4 .22$ & $9: 40$ & 574.00 \\
\hline
\end{tabular}

(7) Hefei

\begin{tabular}{cccccc}
\cline { 1 - 1 } start & & & stop & & dust \\
\cline { 1 - 2 } \cline { 5 - 6 } date & time & & date & time & $\mu \mathrm{g} / \mathrm{m}^{3}$ \\
\hline 2002.3 .15 & $15: 10$ & $\sim 2002.3 .20$ & $15: 58$ & 269.73 \\
2002.3 .21 & $10: 30$ & $\sim 2002.3 .27$ & $16: 41$ & 211.03 \\
2002.3 .30 & $19: 00$ & $\sim 2002.4 .5$ & $16: 04$ & 364.85 \\
2002.4 .12 & $8: 40$ & $\sim 2002.4 .19$ & $14: 35$ & 170.08 \\
\hline
\end{tabular}

Appendix 2a Aeolian dust concentrations in (1) Tsukuba and (2) Nagoya until May 2002 by an Andersen-type low-volume air sampler.

\begin{tabular}{|c|c|c|c|c|c|c|c|c|c|c|c|c|c|c|}
\hline \multirow{3}{*}{ No. } & \multirow{2}{*}{\multicolumn{2}{|c|}{ start }} & \multirow{2}{*}{\multicolumn{2}{|c|}{ stop }} & \multirow{3}{*}{$\begin{array}{l}\text { stage } \\
\text { size } \\
(\mu \mathrm{m})\end{array}$} & \multicolumn{3}{|c|}{ aeolia } & \multirow{3}{*}{$\begin{array}{c}\text { concentr: } \\
3 \\
3.3^{-} \\
4.7\end{array}$} & \multirow{3}{*}{$\begin{array}{l}\text { tion in } \\
4 \\
2.1- \\
3.3 \\
\end{array}$} & \multirow{3}{*}{$\begin{array}{c}\text { each stage } \\
5 \\
1.01- \\
2.1\end{array}$} & \multicolumn{2}{|c|}{$\left(\mu \mathrm{g} / \mathrm{m}^{3}\right)$} & \multirow{3}{*}{$\begin{array}{c}\text { backup } \\
0.43\rangle\end{array}$} \\
\hline & & & & & & 0 & 1 & 2 & & & & 6 & 7 & \\
\hline & date & time & date & time & & $>11.0$ & $\begin{array}{l}7.0^{-} \\
11.0\end{array}$ & $\begin{array}{l}4.7^{-} \\
7.0\end{array}$ & & & & $\begin{array}{l}0.65^{-} \\
1.01\end{array}$ & $\begin{array}{l}0.43^{-} \\
0.65\end{array}$ & \\
\hline 1 & 2001.2 .16 & $15: 55$ & $\sim 2001.2 .23$ & $14: 35$ & & 3.14 & 2.76 & 4.17 & 4.81 & 2.72 & 3.85 & 8.87 & 11.3 & 8.06 \\
\hline 2 & 2001.2. 26 & $17: 05$ & $\sim 2001.4 .26$ & $11: 00$ & & 5. 38 & 3. 30 & 5. 68 & 6. 32 & 4. 17 & 2.58 & 3.96 & 3.95 & 4. 52 \\
\hline 3 & 2001.4 .27 & $11: 43$ & $\sim 2001.5 .21$ & $15: 45$ & & 0.00 & 3. 33 & 5.59 & 7. 47 & 5.22 & 2.99 & 4.55 & 5. 15 & 4. 53 \\
\hline 4 & 2001.5 .22 & $18: 04$ & $\sim 2001.6 .11$ & $15: 43$ & & 1. 75 & 1.66 & 2. 77 & 3.24 & 2. 76 & 3.03 & 5.08 & 4.98 & 2. 66 \\
\hline 5 & 2001. 6. 12 & $12: 45$ & $\sim 2001.7 .2$ & $11: 06$ & & 2. 13 & 1. 76 & 2.01 & 2.47 & 2. 71 & 3. 46 & 6.85 & 5.55 & 3.04 \\
\hline 6 & 2001.7 .2 & $18: 43$ & $\sim 2001.8 .2$ & $9: 06$ & & 3. 44 & 2.81 & 3.15 & 3. 96 & 3. 66 & 2. 80 & 3.52 & 3. 99 & 2. 77 \\
\hline 7 & 2001.8.2 & $16: 42$ & $\sim 2001.8 .21$ & $9: 59$ & & 1. 68 & 1. 30 & 5.72 & 2.31 & 1. 97 & 1. 66 & 3. 34 & 3. 93 & 3. 17 \\
\hline 8 & 2001. 8. 23 & $9: 03$ & $\sim 2001.9 .12$ & $10: 23$ & & 0.00 & 0.38 & 1.91 & 3. 67 & 3.55 & 3.55 & 3.65 & 4.04 & 2.25 \\
\hline 9 & 2001.9.12 & $17: 38$ & $\sim 2001.10 .1$ & $10: 48$ & & 1. 61 & 1.21 & 2.98 & 1.95 & 0.21 & 1.93 & 3. 37 & 2.96 & 3. 34 \\
\hline 10 & 2001. 10. 3 & $15: 15$ & $\sim 2001.10 .22$ & $13: 27$ & & 1.94 & 0.64 & 1. 61 & 2.57 & 1.84 & 1.61 & 3. 12 & 3. 73 & 6.28 \\
\hline 11 & 2001.10 .22 & $17: 15$ & $\sim 2001.11 .12$ & $10: 06$ & & 0.00 & 0.00 & 1. 87 & 1. 49 & 0.00 & 1.67 & 1.08 & 4. 78 & 4. 31 \\
\hline 12 & 2001. 11. 12 & $16: 54$ & $\sim 2001.12 .3$ & $14: 27$ & & 0.85 & 0.50 & 3. 52 & 3.44 & 3.04 & 2.24 & 0.00 & 6.29 & 6. 45 \\
\hline 13 & 2001. 12.3 & $15: 08$ & $\sim 2001.12 .27$ & $9: 38$ & & 2. 69 & 1. 39 & 2. 47 & 2.44 & 2. 09 & 4. 78 & 4. 35 & 3. 35 & 3. 63 \\
\hline 14 & 2001.12 .27 & $15: 01$ & $\sim 2002.1 .21$ & $9: 04$ & & 0.00 & 0.00 & 1. 88 & 2. 36 & 0.44 & 2. 97 & 6.55 & 3. 60 & 4. 19 \\
\hline 15 & 2002.1 .21 & $14: 18$ & $\sim 2002.2 .12$ & $10: 33$ & & 1. 42 & 1.91 & 2. 72 & 2.90 & 2.43 & 0.00 & 5. 49 & 4. 28 & 4. 06 \\
\hline 16 & 2002.2. 12 & $14: 36$ & $\sim 2002.3 .1$ & $10: 54$ & & 7.44 & 3.35 & 4. 59 & 3. 55 & 0.77 & 0.00 & 5. 86 & 4. 05 & 3. 38 \\
\hline 17 & 2002.3 .1 & $14: 53$ & $\sim 2002.3 .20$ & $10: 23$ & & 18.2 & 1. 30 & 10.6 & 4. 72 & 3.94 & 0.00 & 4. 30 & 4. 32 & 6. 74 \\
\hline 18 & 2002. 3. 20 & $17: 05$ & $\sim 2002.4 .1$ & $13: 12$ & & 13.7 & 6.59 & 8.69 & 9.60 & 8.00 & 4. 81 & 4. 37 & 1. 72 & 0.99 \\
\hline 19 & 2002.4 .1 & $14: 55$ & $\sim 2002.4 .8$ & $13: 38$ & & 7. 77 & 4.80 & 8.34 & 8.44 & 6.71 & 4. 49 & 5.83 & 8.16 & 7. 35 \\
\hline 20 & 2002.4 .8 & $14: 19$ & $\sim 2002.4 .12$ & $13: 40$ & & 5.74 & 3. 77 & 16.9 & 30.0 & 28.5 & 6.92 & 5. 13 & 2. 47 & 0.74 \\
\hline 21 & 2002.4 .12 & $14: 08$ & $\sim 2002.4 .17$ & $10: 23$ & & 0.00 & 6.69 & 9.32 & 9.98 & 6.08 & 0.00 & 4. 76 & 3.55 & 1. 37 \\
\hline 22 & 2002.4 .17 & $10: 59$ & $\sim 2002.4 .24$ & $10: 33$ & & 8.29 & 6.43 & 9.70 & 12.2 & 10.6 & 4. 53 & 2.53 & 2. 14 & 2. 00 \\
\hline 23 & 2002.4 .24 & $14: 29$ & $\sim 2002.5 .8$ & $9: 47$ & & 4. 92 & 2. 56 & 1.23 & 1.58 & 2. 45 & 2. 15 & 2. 77 & 2.56 & 2. 44 \\
\hline
\end{tabular}

\begin{tabular}{|c|c|c|c|c|c|c|c|c|c|c|c|c|c|c|}
\hline \multirow{3}{*}{ No. } & \multirow{2}{*}{\multicolumn{2}{|c|}{ start }} & \multirow{2}{*}{\multicolumn{2}{|c|}{ stop }} & \multirow{3}{*}{$\begin{array}{r}\text { stage } \\
\text { size } \\
(\mu \mathrm{m})\end{array}$} & \multicolumn{9}{|c|}{ aeolian dust concentration in each stage $\left(\mu \mathrm{g} / \mathrm{m}^{3}\right)$} \\
\hline & & & & & & 0 & 1 & 2 & 3 & 4 & 5 & 6 & 7 & backup \\
\hline & date & time & date & time & & $>11.0$ & $\begin{array}{l}7.0^{-} \\
11.0\end{array}$ & $\begin{array}{l}4.7- \\
7.0 \\
\end{array}$ & $\begin{array}{l}3.3^{-} \\
4.7 \\
\end{array}$ & $\begin{array}{l}2.1^{-} \\
3.3 \\
\end{array}$ & $\begin{array}{c}1.01^{-} \\
2.1\end{array}$ & $\begin{array}{l}0.65^{-} \\
1.01 \\
\end{array}$ & $\begin{array}{l}0.43^{-} \\
0.65\end{array}$ & $0.43>$ \\
\hline 1 & 2001.3 .8 & $15: 45$ & $\sim 2001.3 .22$ & $11: 10$ & & 8.69 & 6.77 & 11.4 & 11.6 & 9.26 & 6.41 & 8.62 & 7.68 & 8.25 \\
\hline 2 & 2001. 3. 27 & $17: 20$ & $\sim 2001.4 .24$ & $15: 20$ & & 5.59 & 3.44 & 6.47 & 7. 15 & 3. 77 & 3.85 & 5.63 & 6.07 & 5. 89 \\
\hline 3 & 2001. 4. 28 & $15: 15$ & $\sim 2001.5 .16$ & $13: 21$ & & 2. 74 & 2. 16 & 2. 92 & 4.01 & 3.25 & 2.07 & 4. 38 & 4. 92 & 4. 31 \\
\hline 4 & 2001. 5. 19 & $12: 45$ & $\sim 2001.6 .1$ & $9: 55$ & & 3. 26 & 2. 86 & 4. 02 & 4.84 & 4. 40 & 3.45 & 5.91 & 6.10 & 4.93 \\
\hline 5 & 2001.6 .7 & $11: 36$ & $\sim 2001.6 .21$ & $18: 35$ & & 2.25 & 1. 48 & 1. 99 & 2.46 & 2.23 & 3.69 & 7. 49 & 8.47 & 4.96 \\
\hline 6 & 2001.6 .25 & $15: 03$ & $\sim 2001.7 .9$ & $11: 30$ & & 2.82 & 1. 79 & 2. 04 & 2. 46 & 2.23 & 1.97 & 5. 08 & 5.54 & 3. 88 \\
\hline 7 & 2001.8. 18 & $14: 52$ & $\sim 2001.9 .4$ & $18: 04$ & & 1.22 & 0.83 & 1.55 & 2. 15 & 2. 12 & 2. 13 & 5. 04 & 6.62 & 5.56 \\
\hline 8 & 2001.9.17 & $14: 10$ & $\sim 2001.10 .2$ & $13: 23$ & & 3.90 & 3.39 & 3.84 & 4. 10 & 3.93 & 2.90 & 5. 12 & 7.97 & 6. 16 \\
\hline 9 & 2001. 10.4 & $14: 20$ & $\sim 2001.10 .22$ & $15: 01$ & & 0.39 & 0.08 & 1.05 & 2. 31 & 2.42 & 2. 30 & 6.68 & 9.98 & 8. 14 \\
\hline 10 & 2001.10 .25 & $13: 56$ & $\sim 2001.11 .7$ & $14: 35$ & & 2.83 & 2.83 & 4.56 & 3. 86 & 3.15 & 4.80 & 6.84 & 6.25 & 6. 39 \\
\hline 11 & 2001.11 .9 & $12: 05$ & $\sim 2001.11 .26$ & $16: 50$ & & 2. 13 & 0.98 & 2. 94 & 3. 04 & 2. 37 & 3.17 & 5.17 & 6.02 & 6.28 \\
\hline
\end{tabular}


Appendix 2a Continued.

\begin{tabular}{|c|c|c|c|c|c|c|c|c|c|c|c|c|c|c|}
\hline \multirow{3}{*}{ No. } & \multirow{2}{*}{\multicolumn{2}{|c|}{ start }} & \multirow{2}{*}{\multicolumn{2}{|c|}{ stop }} & \multirow{3}{*}{$\begin{array}{r}\text { stage } \\
\text { size } \\
(\mu \mathrm{m})\end{array}$} & \multicolumn{9}{|c|}{ aeolian dust concentration in each stage $\left(\mu \mathrm{g} / \mathrm{m}^{3}\right)$} \\
\hline & & & & & & 0 & 1 & 2 & 3 & 4 & 5 & 6 & 7 & backup \\
\hline & date & time & date & time & & $>11.0$ & $\begin{array}{l}7.0^{-} \\
11.0^{-}\end{array}$ & $\begin{array}{l}4.7- \\
7.0\end{array}$ & $\begin{array}{l}3.3^{-} \\
4.7\end{array}$ & $\begin{array}{l}2.1^{-} \\
3.3\end{array}$ & $\begin{array}{c}1.01^{-} \\
2.1\end{array}$ & $\begin{array}{l}0.65- \\
1.01\end{array}$ & $\begin{array}{l}0.43^{-} \\
0.65\end{array}$ & $0.43>$ \\
\hline 12 & 2001.12 .4 & $15: 30$ & $\sim 2001.12 .19$ & $15: 20$ & & 2.11 & 1.91 & 2.21 & 2.24 & 2.03 & 2.16 & 3.04 & 1.80 & 2.78 \\
\hline 13 & 2002.2 .1 & $15: 45$ & $\sim 2002.2 .15$ & $13: 25$ & & 2. 28 & 1.99 & 3. 23 & 2.91 & 2. 84 & 2. 59 & 4. 39 & 5. 37 & 4. 89 \\
\hline 14 & 2002.2 .15 & $19: 30$ & $\sim 2002.3 .1$ & $11: 30$ & & 1.85 & 1.81 & 2.85 & 3.09 & 2. 77 & 2. 77 & 5. 12 & 5.87 & 5. 08 \\
\hline 15 & 2002. 3.4 & $12: 53$ & $\sim 2002.3 .18$ & $12: 43$ & & 4. 17 & 3. 37 & 5.45 & 7. 96 & 5.89 & 4. 42 & 6. 16 & 6.19 & 5. 45 \\
\hline 16 & 2002. 3. 18 & $15: 40$ & $\sim 2002.4 .2$ & $12: 17$ & & 5. 09 & 4.51 & 10.1 & 14.0 & 11. 2 & 5.20 & 4. 38 & 6.21 & 5. 75 \\
\hline 17 & 2002.4 .2 & $17: 59$ & $\sim 2002.4 .8$ & $8: 56$ & & 6.15 & 3. 75 & 7. 72 & 7. 11 & 6.07 & 3.97 & 4. 80 & 9.51 & 8.99 \\
\hline 18 & 2002.4 .8 & $10: 37$ & $\sim 2002.4 .12$ & $12: 36$ & & 9.02 & 7.63 & 24.6 & 40.7 & 33.1 & 12.6 & 6.79 & 10.4 & 10.5 \\
\hline 19 & 2002.4 .12 & $14: 55$ & $\sim 2002.4 .15$ & $15: 32$ & & 7. 79 & 4. 30 & 8.84 & 12.3 & 11.9 & 6. 33 & 7. 87 & 23.0 & 13.7 \\
\hline 20 & 2002.4 .16 & $15: 59$ & $\sim 2002.4 .21$ & $10: 59$ & & 6.61 & 6.76 & 12.4 & 15.7 & 12.9 & 5.99 & 5.63 & 8.19 & 8.04 \\
\hline 21 & 2002. 4.22 & $17: 26$ & $\sim 2002.5 .8$ & $13: 32$ & & 3. 01 & 2.51 & 4. 46 & 4.99 & 3. 98 & 2.97 & 4. 12 & 5. 36 & 4. 74 \\
\hline 22 & 2002.5 .9 & $12: 26$ & $\sim 2002.5 .22$ & $13: 15$ & & 2. 79 & 1. 68 & 2.88 & 2. 99 & 3. 61 & 3. 93 & 6.51 & 3. 73 & 2. 28 \\
\hline
\end{tabular}

Appendix 2b Aeolian dust concentrations in (3) Fukuoka and (4) Naha until May 2002 by an Andersen-type low-volume air sampler.

\begin{tabular}{|c|c|c|c|c|c|c|c|c|c|c|c|c|c|c|}
\hline \multirow{3}{*}{ No. } & \multirow{2}{*}{\multicolumn{2}{|c|}{ start }} & \multirow{2}{*}{\multicolumn{2}{|c|}{ stop }} & \multirow{3}{*}{$\begin{array}{l}\text { stage } \\
\text { size } \\
(\mu \mathrm{m})\end{array}$} & \multicolumn{9}{|c|}{ aeolian dust concentration in each stage $\left(\mu \mathrm{g} / \mathrm{m}^{2}\right)$} \\
\hline & & & & & & \multirow{2}{*}{$\begin{array}{c}0 \\
>11.0\end{array}$} & \multirow{2}{*}{$\begin{array}{c}1 \\
7.0- \\
11.0 \\
\end{array}$} & \multirow{2}{*}{\begin{tabular}{l}
\multicolumn{1}{c}{2} \\
$4.7-$ \\
7.0
\end{tabular}} & \multirow{2}{*}{$\begin{array}{c}3 \\
3.3- \\
4.7 \\
\end{array}$} & \multirow{2}{*}{$\begin{array}{l}4 \\
2.1- \\
3.3 \\
\end{array}$} & \multirow{2}{*}{$\begin{array}{c}5 \\
1.01- \\
2.1\end{array}$} & \multirow{2}{*}{$\begin{array}{l}6 \\
0.65- \\
1.01 \\
\end{array}$} & \multirow{2}{*}{$\begin{array}{l}7 \\
0.43- \\
0.65 \\
\end{array}$} & \multirow{2}{*}{$\begin{array}{l}\text { backup } \\
0.43>\end{array}$} \\
\hline & date & time & date & time & & & & & & & & & & \\
\hline 1 & 2001.5 .17 & $11: 45$ & $\sim 2001.5 .24$ & $10: 30$ & & 6.36 & 7.77 & 5.65 & 7.42 & 9.54 & 2.83 & 5.65 & 6.71 & $\overline{5.65}$ \\
\hline 2 & 2001. 5.24 & $11: 11$ & $\sim 2001.5 .31$ & $10: 08$ & & 4. 23 & 2. 47 & 3. 17 & 3.53 & 3. 88 & 3. 88 & 10.2 & 7. 41 & 2. 12 \\
\hline 3 & 2001.6 .1 & $11: 11$ & $\sim 2001.6 .7$ & $10: 20$ & & 4. 53 & 4. 94 & 0.41 & 6.58 & 0.41 & 5.76 & 8. 64 & 6.58 & 5. 76 \\
\hline 4 & 2001.6 .7 & $14: 39$ & $\sim 2001.6 .14$ & $10: 31$ & & 0.36 & 1. 80 & 4. 67 & 5. 39 & 1. 80 & 2. 52 & 10.8 & 11.5 & 6. 47 \\
\hline 5 & 2001. 6. 14 & $13: 54$ & $\sim 2001.6 .19$ & $14: 00$ & & 2.45 & 2. 45 & 1. 47 & 6.37 & 0.00 & 3.43 & 1. 47 & 0.49 & 0.98 \\
\hline 6 & 2001. 6.20 & $13: 58$ & $\sim 2001.6 .27$ & $10: 37$ & & 1.07 & 1. 07 & 1.07 & 3.58 & 2. 50 & 1. 43 & 1. 43 & 4. 29 & 3.58 \\
\hline 7 & 2001.6 .27 & $18: 57$ & $\sim 2001.7 .4$ & $10: 48$ & & 1.11 & 1. 47 & 0.74 & 0.00 & 4. 79 & 0.74 & 2. 58 & 3. 68 & 1. 47 \\
\hline 8 & 2001. 7.4 & $14: 23$ & $\sim 2001.7 .11$ & $11: 10$ & & 0.36 & 0.00 & 0.36 & 0.00 & 2. 14 & 0.00 & 1. 79 & 5. 72 & 3. 22 \\
\hline 9 & 2001.7.11 & $14: 18$ & $\sim 2001.7 .19$ & $9: 14$ & & 2.52 & 1. 58 & 0.00 & 0.00 & 0.32 & 0.32 & 0.63 & 3.15 & 0.63 \\
\hline 10 & 2001.7.19 & $13: 16$ & $\sim 2001.7 .26$ & $11: 00$ & & 0.36 & 1.42 & 3.20 & 1. 78 & 0.71 & 3.55 & 1.78 & 6.04 & 3.91 \\
\hline 11 & 2001.7.26 & $16: 26$ & $\sim 2001.8 .2$ & $13: 02$ & & 2.15 & 1.07 & 2.86 & 5.01 & 2. 15 & 2.50 & 7. 16 & 10.7 & 8.23 \\
\hline 12 & 2001.8 .2 & $16: 51$ & $\sim 2001.8 .9$ & $10: 25$ & & 17.9 & 2. 92 & 0.00 & 5.47 & 51.4 & 0.00 & 6. 93 & 11.3 & 5.83 \\
\hline 13 & 2001.8 .9 & $12: 51$ & $\sim 2001.8 .23$ & $11: 31$ & & 1.23 & 0.70 & 1. 94 & 2. 99 & 2. 64 & 0.00 & 3.17 & 5. 10 & 4. 05 \\
\hline 14 & 2001.8 .24 & $11: 53$ & $\sim 2001.8 .31$ & $17: 23$ & & 2. 72 & 0.34 & 0.34 & 0.34 & 2. 38 & 2. 38 & 6. 45 & 17.0 & 4. 75 \\
\hline 15 & 2001.8 .31 & $18: 19$ & $\sim 2001.9 .7$ & $10: 40$ & & 0.00 & 0.00 & 0.00 & 5.88 & 0.73 & 0.00 & 0.00 & 3. 31 & 4. 04 \\
\hline 16 & 2001.9 .7 & $16: 20$ & $\sim 2001.9 .14$ & $10: 03$ & & 4.01 & 0.73 & 3.28 & 1.09 & 1. 09 & 0.00 & 0.73 & 3.28 & 2. 19 \\
\hline 17 & 2001.9. 14 & $20: 14$ & $\sim 2001.9 .21$ & $9: 27$ & & 1.50 & 3. 00 & 3.00 & 4.50 & 3. 37 & 0.00 & 2. 62 & 7. 87 & 2. 62 \\
\hline 18 & 2001.9. 22 & $17: 13$ & $\sim 2001.9 .28$ & $10: 20$ & & 1.29 & 0.43 & 1. 72 & 4. 30 & 2. 15 & 2.58 & 1. 72 & 7. 73 & 6. 44 \\
\hline 19 & 2001.9.28 & $14: 11$ & $\sim 2001.10 .5$ & $7: 55$ & & 0.73 & 1.09 & 5.10 & 3.28 & 5.46 & 0.73 & 1.82 & 5.83 & 4. 37 \\
\hline 20 & 2001.10 .5 & $14: 33$ & $\sim 2001.10 .12$ & $10: 30$ & & 3.95 & 2. 16 & 2.87 & 3.95 & 3. 23 & 2.51 & 6.83 & 7.54 & 5. 03 \\
\hline 21 & 2001.10 .12 & $15: 55$ & $\sim 2001.10 .19$ & $10: 25$ & & 3.26 & 2. 17 & 3.26 & 1. 45 & 2. 17 & 1. 09 & 3.26 & 6. 52 & 7. 61 \\
\hline 22 & 2001. 10. 19 & $13: 59$ & $\sim 2001.10 .26$ & $11: 51$ & & 2.13 & 1. 78 & 1. 42 & 2.84 & 4. 26 & 2. 13 & 3. 20 & 4.62 & 4. 26 \\
\hline 23 & 2001.10 .26 & $14: 26$ & $\sim 2001.11 .2$ & $10: 05$ & & 1.80 & 1. 80 & 2.52 & 2. 88 & 2. 52 & 7.20 & 7.56 & 8. 64 & 6. 48 \\
\hline 24 & 2001. 11.2 & $15: 00$ & $\sim 2001.11 .9$ & $10: 05$ & & 1.08 & 1. 44 & 3.: & 2.17 & 5. 06 & 1. 44 & 2.53 & 2. 17 & 1. 08 \\
\hline 25 & 2001.11 .9 & $18: 00$ & $\sim 2001.11 .16$ & $12: 03$ & & 3.2 & 1. 09 & 0 . & 1.09 & 3.27 & 2. 18 & 1. 09 & 4. 72 & 4. 72 \\
\hline 26 & 2001.11 .26 & $14: 25$ & $\sim 2001.12 .3$ & $11: 00$ & & 2.15 & 0.00 & 2.50 & 2.15 & 1. 43 & 0.72 & 4. 29 & 8. 23 & 3. 94 \\
\hline 27 & 2001.12 .4 & $14: 40$ & $\sim 2001.12 .27$ & $13: 06$ & & 1.28 & 0.86 & 2.25 & 2. 78 & 2. 46 & 1.50 & 2. 25 & 4. 28 & 4. 07 \\
\hline 28 & 2001. 12.28 & $17: 28$ & $\sim 2002.1 .17$ & $11: 40$ & & 3. 48 & 1. 99 & 3.85 & 4. 72 & 5. 34 & 3.23 & 4. 60 & 6.71 & 4. 35 \\
\hline 29 & 2002.1.21 & $12: 50$ & $\sim 2002.2 .12$ & $10: 42$ & & 2. 69 & 3. 36 & 0.00 & 38.1 & 4. 26 & 2. 46 & 4. 03 & 4.82 & 2. 91 \\
\hline 30 & 2002.2. 14 & $10: 38$ & $\sim 2002.3 .1$ & $10: 10$ & & 3. 60 & 2. 46 & 3.60 & 3. 77 & 3.44 & 3.28 & 5. 08 & 8.35 & 5.57 \\
\hline 31 & 2002.3.1 & $12: 28$ & $\sim 2002.3 .22$ & $11: 24$ & & 7.03 & 5.50 & 11.5 & 19.2 & 17.6 & 7.61 & 7.73 & 7.03 & 4. 10 \\
\hline 32 & 2002. 3. 22 & $16: 11$ & $\sim 2002.4 .5$ & $19: 00$ & & 7.23 & 8.00 & 8. 19 & 12.9 & 10.9 & 4. 22 & 3.22 & 4. 00 & 4. 08 \\
\hline 33 & 2002.4 .6 & $9: 15$ & $\sim 2002.4 .11$ & $15: 36$ & & 10.3 & 17.0 & 37.3 & 46.7 & 53.4 & 17.9 & 6. 95 & 7. 32 & 7. 55 \\
\hline 34 & 2002.4. 12 & $11: 34$ & $\sim 2002.4 .16$ & $12: 39$ & & 1.64 & 0.00 & 6.13 & 14.9 & 6.43 & 0.00 & 18.8 & 18.0 & 0.73 \\
\hline 35 & 2002.4 .17 & $10: 37$ & $\sim 2002.4 .25$ & $9: 03$ & & 5.57 & 5.44 & 5.91 & 6.96 & 5.23 & 5. 32 & 1.95 & 5. 10 & 12.2 \\
\hline 36 & 2002.4 .25 & $9: 05$ & $\sim 2002.5 .10$ & $17: 50$ & & 7.87 & 0.00 & 1.55 & 4. 58 & 1.50 & 0.00 & 2.95 & 5.59 & 3.51 \\
\hline
\end{tabular}

\begin{tabular}{|c|c|c|c|c|c|c|c|c|c|c|c|c|c|c|}
\hline \multirow{3}{*}{ No. } & \multirow{2}{*}{\multicolumn{2}{|c|}{ start }} & \multirow{2}{*}{\multicolumn{2}{|c|}{ stop }} & \multirow{3}{*}{$\begin{array}{l}\text { stage } \\
\text { size } \\
(\mu \mathrm{m})\end{array}$} & \multicolumn{9}{|c|}{ aeolian dust concentration in each stage $\left(\mu \mathrm{g} / \mathrm{m}^{3}\right)$} \\
\hline & & & & & & 0 & 1 & 2 & 3 & 4 & & 6 & 7 & backup \\
\hline & date & time & date & time & & $>11.0$ & $\begin{array}{l}7.0^{-} \\
11.0\end{array}$ & $\begin{array}{l}4.7- \\
7.0\end{array}$ & $\begin{array}{l}3.3^{-} \\
4.7\end{array}$ & $\begin{array}{l}2.1^{-} \\
3.3\end{array}$ & $\begin{array}{c}1.01^{-} \\
2.1\end{array}$ & $\begin{array}{l}0.65^{-} \\
1.01\end{array}$ & $\begin{array}{l}0.43^{-} \\
0.65\end{array}$ & $0.43>$ \\
\hline 1 & 2001.5 .31 & $9: 20$ & $\sim 2001.6 .11$ & $16: 45$ & & 1.08 & 1.15 & 2.19 & 2.69 & 2.02 & 0.48 & 2.21 & 2.13 & 1.58 \\
\hline 2 & 2001.6.15 & $17: 15$ & $\sim 2001.6 .25$ & $17: 20$ & & 1. 69 & 1.52 & 3.34 & 4. 98 & 2.72 & 1.20 & 0.47 & 1.77 & 2. 18 \\
\hline 3 & 2001. 6. 28 & $17: 30$ & $\sim 2001.7 .10$ & $8: 40$ & & 1. 98 & 2. 43 & 3. 27 & 4. 79 & 0.19 & 2.03 & 0.00 & 0.25 & 0.00 \\
\hline 4 & 2001. 7. 10 & $18: 50$ & $\sim 2001.7 .19$ & $17: 00$ & & 0.00 & 0.00 & 0.00 & 1. 10 & 2.50 & 0.71 & 0.69 & 5. 28 & 0.00 \\
\hline 5 & 1997.7 .19 & $8: 51$ & $\sim 1997.7 .29$ & $17: 23$ & & 1. 30 & 0.62 & 2.11 & 2.42 & 1.85 & 0.00 & 0.28 & 0.31 & 0.21 \\
\hline 6 & 1997.8 .1 & $8: 54$ & $\sim 1997.8 .12$ & $9: 32$ & & 0.00 & 0.00 & 0.00 & 3.07 & 0.00 & 3.14 & 8.43 & 4. 43 & 0.71 \\
\hline 7 & 1997.8.19 & $15: 50$ & $\sim 1997.9 .9$ & $14: 42$ & & 0.43 & 1.65 & 3.08 & 2. 99 & 2.74 & 0.00 & 0.57 & 1. 30 & 0.00 \\
\hline 8 & 1997.9 .9 & $17: 34$ & $\sim 1997.9 .30$ & $17: 01$ & & 1.08 & 1. 75 & 2. 97 & 3.73 & 2.32 & 1. 29 & 0.00 & 0.41 & 0.00 \\
\hline 9 & 1997. 10. 2 & $17: 34$ & $\sim 1997.10 .22$ & $9: 58$ & & 3.05 & 2. 72 & 6.41 & 6.57 & 4.35 & 2.44 & 4. 45 & 3. 50 & 1. 99 \\
\hline 10 & 1997. 10.22 & $13: 15$ & $\sim 1997.11 .11$ & $16: 00$ & & 2. 76 & 2.81 & 4. 93 & 5.27 & 3.04 & 1. 18 & 3.01 & 7. 19 & 1. 46 \\
\hline 11 & 1997.11 .12 & $9: 00$ & $\sim 1997.12 .2$ & $9: 00$ & & 3.41 & 3.35 & 6.22 & 5.50 & 5.17 & 1.40 & 5.28 & 3.77 & 2. 42 \\
\hline 12 & 2001. 12.26 & 9:00 & $\sim 2002.1 .15$ & $8: 56$ & & 2.41 & 3.55 & 13.2 & 7.44 & 4.61 & 3.73 & 5.74 & 5. 76 & 3. 62 \\
\hline 13 & 2002.1 .15 & $17: 24$ & $\sim 2002.2 .4$ & $16: 18$ & & 1. 98 & 1.87 & 5.39 & 5.61 & 3.43 & 2.15 & 3.74 & 3. 84 & 2. 46 \\
\hline
\end{tabular}


Appendix 2b Continued.

\begin{tabular}{|c|c|c|c|c|c|c|c|c|c|c|c|c|c|c|}
\hline \multirow{3}{*}{ No. } & \multirow{2}{*}{\multicolumn{2}{|c|}{ start }} & \multirow{2}{*}{\multicolumn{2}{|c|}{ stop }} & \multirow{3}{*}{$\begin{array}{l}\text { stage } \\
\text { size } \\
(\mu \mathrm{m})\end{array}$} & \multicolumn{9}{|c|}{ aeolian dust concentration in each stage $\left(\mu \mathrm{g} / \mathrm{m}^{3}\right)$} \\
\hline & & & & & & 0 & 1 & 2 & 3 & 4 & 5 & 6 & 7 & backup \\
\hline & date & time & date & time & & $>11.0$ & $\begin{array}{l}\text { 7.0- } \\
11.0\end{array}$ & $\begin{array}{l}4.7^{-} \\
7.0\end{array}$ & $\begin{array}{l}3.3^{-} \\
4.7\end{array}$ & $\begin{array}{l}2.1^{-} \\
3.3\end{array}$ & $\begin{array}{c}1.01^{-} \\
2.1 \\
\end{array}$ & $\begin{array}{l}0.65^{-} \\
1.01 \\
\end{array}$ & $\begin{array}{l}0.43^{-} \\
0.65\end{array}$ & $0.43>$ \\
\hline 14 & 2002.2 .5 & $8: 58$ & $\sim 2002.2 .25$ & $16: 30$ & & 3.54 & 3.94 & 7.32 & 6.50 & 4.86 & 2.37 & 4.66 & 4.01 & 2.94 \\
\hline 15 & 2002.2.26 & $11: 40$ & $\sim 2002.3 .18$ & $10: 19$ & & 3. 14 & 2. 63 & 6.19 & 6.63 & 4. 69 & 3. 10 & 4. 07 & 3. 74 & 3. 15 \\
\hline 16 & 2002.3. 18 & $17: 00$ & $\sim 2002.4 .7$ & $7: 33$ & & 3. 67 & 3.93 & 11.0 & 13.4 & 9. 34 & 4. 44 & 3. 14 & 3.88 & 2. 58 \\
\hline 17 & 2002.4 .7 & $9: 50$ & $\sim 2002.4 .17$ & $7: 11$ & & 3. 32 & 5.96 & 14. 9 & 19.0 & 14.9 & 5.63 & 3. 25 & 5.16 & 3.90 \\
\hline 18 & 2002.4 .17 & $8: 42$ & $\sim 2002.4 .24$ & $17: 02$ & & 0.00 & 0.00 & 6.85 & 4. 04 & 11. 6 & 0.00 & 3. 24 & 4. 48 & 4. 31 \\
\hline 19 & 2002.4 .25 & $8: 20$ & $\sim 2002.5 .15$ & $9: 05$ & & 2.85 & 1.45 & 2.88 & 0.00 & 6.20 & 0.00 & 1.31 & 2. 49 & 2.96 \\
\hline
\end{tabular}

Appendix 2c Aeolian dust concentrations in (5) Qingdao, (6) Beijing and (7) Hefei until May 2002 by an Andersen-type low-volume air sampler.

(5) Qingdao

\begin{tabular}{|c|c|c|c|c|c|c|c|c|c|c|c|c|c|c|}
\hline \multirow{3}{*}{ No. } & \multirow{2}{*}{\multicolumn{2}{|c|}{ start }} & \multirow{2}{*}{\multicolumn{2}{|c|}{ stop }} & \multirow{3}{*}{$\begin{array}{l}\text { stage } \\
\text { size } \\
(\mu \mathrm{m})\end{array}$} & \multicolumn{9}{|c|}{ aeolian dust concentration in each stage $\left(\mu \mathrm{g} / \mathrm{m}^{2}\right)$} \\
\hline & & & & & & \multirow{2}{*}{$\begin{array}{c}0 \\
>11.0\end{array}$} & \multirow{2}{*}{$\begin{array}{c}1 \\
7.0- \\
11.0\end{array}$} & \multirow{2}{*}{$\begin{array}{l}2 \\
4.7- \\
7.0\end{array}$} & \multirow{2}{*}{$\begin{array}{c}3 \\
3.3^{-} \\
4.7\end{array}$} & \multirow{2}{*}{$\begin{array}{l}4 \\
2.1- \\
3.3\end{array}$} & \multirow{2}{*}{$\begin{array}{l}5 \\
1.01- \\
2.1\end{array}$} & \multirow{2}{*}{$\begin{array}{l}6 \\
0.65- \\
1.01\end{array}$} & \multirow{2}{*}{$\begin{array}{l}7 \\
0.43- \\
0.65\end{array}$} & \multirow{2}{*}{$\begin{array}{c}\text { backup } \\
0.43>\end{array}$} \\
\hline & date & time & date & time & & & & & & & & & & \\
\hline 1 & 2001.5 .1 & $8: 30$ & $\sim 2001.5 .9$ & $8: 25$ & & 2.15 & 3.68 & 5.83 & 6.14 & 5.83 & 3.99 & 10.4 & 8.29 & - \\
\hline 2 & 2001. 5.9 & $8: 50$ & $\sim 2001.5 .15$ & $8: 00$ & & 4. 52 & 6.58 & 7.82 & 9. 46 & 8.23 & 5.76 & 6.58 & 9.05 & - \\
\hline 3 & 2001.6 .6 & $9: 45$ & $\sim 2001.6 .12$ & $9: 30$ & & 1.64 & 3. 69 & 2.87 & 4. 51 & 3.69 & 6.56 & 10.7 & 5.74 & - \\
\hline 4 & 2001. 6.24 & $9: 00$ & $\sim 2001.6 .29$ & $10: 00$ & & 1.95 & 2. 43 & 3. 41 & 3.41 & 1.95 & 9. 73 & 13.1 & 139. & - \\
\hline 5 & 2001. 7.2 & $14: 35$ & $\sim 2001.7 .5$ & $14: 35$ & & 6.54 & 5. 73 & 7. 36 & 8.18 & 8. 18 & 13.9 & 18.8 & 12.3 & 15.5 \\
\hline 6 & 2001.7 .25 & $10: 14$ & $\sim 2001.7 .29$ & $10: 14$ & & 1.84 & 3. 68 & 5.52 & 10.4 & 6. 75 & 7. 36 & 11.0 & 9.20 & 9.20 \\
\hline 7 & 2001.8 .11 & $10: 50$ & $\sim 2001.8 .17$ & $10: 11$ & & 2.46 & 0.41 & 0.00 & 2. 46 & 1. 64 & 3.29 & 2. 46 & 4. 11 & 31.6 \\
\hline 8 & 2001.8 .17 & $10: 15$ & $\sim 2001.8 .21$ & $16: 35$ & & 4. 25 & 3. 64 & 5. 46 & 4.85 & 0.61 & 3. 03 & 6.67 & 4. 85 & 6.07 \\
\hline 9 & 2001.9.8 & $10: 03$ & $\sim 2001.9 .13$ & $10: 10$ & & 6.86 & 4. 90 & 10.3 & 10.3 & 5.88 & 5.39 & 10.3 & 7.84 & 7. 35 \\
\hline 10 & 2001.9 .20 & $13: 25$ & $\sim 2001.9 .25$ & $13: 25$ & & 7. 36 & 7.85 & 19.1 & 6.87 & 6.38 & 11.3 & 29.9 & 5.89 & 8. 34 \\
\hline 11 & 2001.10 .7 & $9: 50$ & $\sim 2001.10 .11$ & $10: 10$ & & 2. 45 & 0.00 & 4. 28 & 7. 34 & 5. 50 & 13.4 & 43.4 & 7. 34 & 5.50 \\
\hline 12 & 2001.10 .25 & $14: 47$ & $\sim 2001.10 .29$ & $15: 40$ & & 12.8 & 11.5 & 8.51 & 9.12 & 7.90 & 12.2 & 24.9 & 6.08 & 5.47 \\
\hline 13 & 2001.11 .12 & $9: 15$ & $\sim 2001.11 .16$ & $9: 15$ & & 4. 29 & 0.00 & 13.5 & 5. 52 & 3.07 & 8.59 & 57.1 & 11.0 & 24.5 \\
\hline 14 & 2001.11 .21 & $10: 30$ & $\sim 2001.11 .26$ & $15: 25$ & & 3. 30 & 42.4 & 23.1 & 19.8 & 15.1 & 13.7 & 31.1 & 9.90 & 10.4 \\
\hline 15 & 2002.1 .5 & $11: 30$ & $\sim 2002.1 .9$ & $11: 30$ & & 11.7 & 17.2 & 22.1 & 16.0 & 16. 6 & 11.0 & 19.6 & 126. & 10.4 \\
\hline 16 & 2002.1 .17 & $10: 30$ & $\sim 2002.1 .21$ & $10: 30$ & & 0.61 & 4. 29 & 14.1 & 14. 7 & 19. 6 & 27.0 & 25.8 & 11. 7 & 20.9 \\
\hline 17 & 2002.2 .3 & $12: 25$ & $\sim 2002.2 .7$ & $10: 25$ & & 0.00 & 16.9 & 21.9 & 3. 13 & 1.88 & 6.27 & 18.8 & 19.4 & 14.4 \\
\hline 18 & 2002.2.18 & $10: 00$ & $\sim 2002.2 .25$ & $8: 15$ & & 2.83 & 7.44 & 13.1 & 19.1 & 7.08 & 7. 79 & 8.15 & 11.7 & 14.2 \\
\hline 19 & 2002.3. 8 & $11: 30$ & $\sim 2002.3 .14$ & $11: 30$ & & 7. 77 & 11.0 & 9.82 & 3. 27 & 11.5 & 6.13 & 15.5 & 7. 36 & 4. 91 \\
\hline 20 & 2002.3 .20 & $10: 45$ & $\sim 2002.3 .23$ & $10: 15$ & & 0.00 & 51.1 & 114. & 106. & 125. & 34.6 & 18.1 & 15.6 & 8. 24 \\
\hline 21 & 2002.4.1 & $16: 30$ & $\sim 2002.4 .4$ & $15: 30$ & & 23.2 & 13. 3 & 30.7 & 36.5 & 33.2 & 26.5 & 15.8 & 24.1 & 19.9 \\
\hline 22 & 2002. 4.8 & $19: 00$ & $\sim 2002.4 .13$ & $15: 38$ & & 25.2 & 16. 7 & 10.1 & 38.4 & 10.1 & 18.2 & 8.58 & 2.02 & 6. 56 \\
\hline 23 & 2002.4 .15 & $13: 30$ & $\sim 2002.4 .19$ & $16: 30$ & & 11.9 & 4. 16 & 1. 19 & 6.54 & 19.04 & 0.00 & 8.33 & 8.92 & 10.7 \\
\hline
\end{tabular}

(6) Bei jing

\begin{tabular}{|c|c|c|c|c|c|c|c|c|c|c|c|c|c|c|}
\hline \multirow{3}{*}{ No. } & \multirow{2}{*}{\multicolumn{2}{|c|}{ start }} & \multirow{2}{*}{\multicolumn{2}{|c|}{ stop }} & \multirow{3}{*}{$\begin{array}{l}\text { stage } \\
\text { size } \\
(\mu \mathrm{m})\end{array}$} & \multicolumn{9}{|c|}{ aeolian dust concentration in each stage $\left(\mu \mathrm{g} / \mathrm{m}^{3}\right)$} \\
\hline & & & & & & \multirow{2}{*}{$\begin{array}{c}0 \\
>11.0\end{array}$} & \multirow{2}{*}{$\begin{array}{c}1 \\
7.0- \\
11.0\end{array}$} & \multirow{2}{*}{\begin{tabular}{l}
\multicolumn{1}{c}{2} \\
$4.7-$ \\
7.0
\end{tabular}} & \multirow{2}{*}{$\begin{array}{l}3 \\
3.3- \\
4.7\end{array}$} & \multirow{2}{*}{$\begin{array}{l}4 \\
2.1- \\
3.3 \\
\end{array}$} & \multirow{2}{*}{$\begin{array}{c}5 \\
1.01- \\
2.1\end{array}$} & \multirow{2}{*}{$\begin{array}{l}6 \\
0.65^{-} \\
1.01\end{array}$} & \multirow{2}{*}{$\begin{array}{l}7 \\
0.43- \\
0.65 \\
\end{array}$} & \multirow{2}{*}{$\begin{array}{l}\text { backup } \\
0.43>\end{array}$} \\
\hline & date & time & date & time & & & & & & & & & & \\
\hline 1 & 2002.2 .27 & $10: 00$ & $\sim 2002.3 .4$ & $10: 00$ & & 27.5 & 19.6 & 31.4 & 27.5 & 16.7 & 25.5 & 26.0 & 11.8 & 15.2 \\
\hline 2 & 2002.3.19 & $10: 00$ & $\sim 2002.3 .21$ & $10: 00$ & & 189. & 304. & 205. & 161. & 103. & 49.1 & 18. 4 & 11.0 & 16.0 \\
\hline 3 & 2002.4 .8 & $9: 30$ & $\sim 2002.4 .8$ & $21: 00$ & & 476. & 261. & 215. & 118. & 133. & 102. & 30.7 & 66.6 & 61.5 \\
\hline 4 & 2002.4.11 & $18: 15$ & $\sim 2002.4 .12$ & $9: 15$ & & 275. & 120. & 120. & 113. & 78.5 & 29.4 & 22.1 & 12.3 & 14.7 \\
\hline 5 & 2002.4 .14 & $13: 30$ & $\sim 2002.4 .15$ & $13: 30$ & & 185. & 86.4 & 110. & 110. & 94.2 & 55.0 & 31.4 & 11.8 & 7. 85 \\
\hline 6 & 2002.4.15 & $15: 50$ & $\sim 2002.4 .16$ & $15: 50$ & & 196. & 63.8 & 101. & 98.2 & 68.7 & 31.9 & 17.2 & 9.82 & 2. 45 \\
\hline 7 & 2002.4 .16 & $16: 00$ & $\sim 2002.4 .17$ & $10: 00$ & & 134. & 55.6 & 39.3 & 16.4 & 32.7 & 0.00 & 0.00 & 6.54 & 52.3 \\
\hline 8 & 2002. 4.17 & $10: 30$ & $\sim 2002.4 .19$ & $10: 30$ & & 62.6 & 41.7 & 51.5 & 40.5 & 19. 6 & 12.3 & 14. 7 & 22.1 & 24.5 \\
\hline 9 & 2002.4 .21 & $9: 40$ & $\sim 2002.4 .22$ & $9: 40$ & & 101. & 41.7 & 44.2 & 31.9 & 24.5 & 34.4 & 36.8 & 7.36 & 7.36 \\
\hline
\end{tabular}

(7) Hefei

\begin{tabular}{|c|c|c|c|c|c|c|c|c|c|c|c|c|c|c|}
\hline \multirow{3}{*}{ No. } & & & & & \multirow{3}{*}{$\begin{array}{c}\text { stage } \\
\text { size } \\
(\mu \mathrm{m})\end{array}$} & \multicolumn{9}{|c|}{ aeolian dust concentration in each stage $\left(\mu \mathrm{g} / \mathrm{m}^{3}\right)$} \\
\hline & \multicolumn{2}{|c|}{ start } & \multicolumn{2}{|l|}{ stop } & & 0 & 1 & 2 & 3 & 4 & 5 & 6 & 7 & backup \\
\hline & date & time & date & time & & $>11.0$ & $\begin{array}{l}7.0- \\
11.0\end{array}$ & $\begin{array}{l}4.7- \\
7.0\end{array}$ & $\begin{array}{l}3.3^{-} \\
4.7\end{array}$ & $\begin{array}{l}2.1^{-} \\
3.3\end{array}$ & $\begin{array}{c}1.01- \\
2.1\end{array}$ & $\begin{array}{l}0.65- \\
1.01\end{array}$ & $\begin{array}{l}0.43- \\
0.65\end{array}$ & $0.43>$ \\
\hline 1 & 2002.3 .15 & $15: 50$ & $\sim 2002.3 .20$ & $16: 00$ & & 18.0 & 17.0 & 27.1 & 26.9 & 19.2 & 13.9 & 18.5 & 7.20 & $\overline{4.56}$ \\
\hline 2 & 2002.3.21 & $14: 21$ & $\sim 2002.3 .28$ & $9: 40$ & & 13.3 & 13. 7 & 18.6 & 27.2 & 19.9 & 11.8 & 14.5 & 11.7 & 5. 70 \\
\hline 3 & 2002.3. 30 & $18: 50$ & $\sim 2002.4 .5$ & $16: 18$ & & 31.4 & 16.9 & 45.3 & 45.7 & 21.7 & 15.7 & 24.5 & 14.0 & 36.9 \\
\hline 4 & 2002.4 .12 & $8: 45$ & $\sim 2002.4 .19$ & $14: 37$ & & 14.9 & 9.17 & 15.6 & 22.4 & 22.4 & 13.7 & 15.0 & 11.7 & 6. 14 \\
\hline
\end{tabular}


Variation of concentrations and physicochemical properties of aeolian dust obtained in east China and Japan

from 2001 to 2002 (kanai et.al)

Appendix 3 Place names in China (After S.Yabuki)

\begin{tabular}{|c|c|c|c|c|}
\hline $\begin{array}{c}\text { Chinese } \\
\text { pinyin }\end{array}$ & English & $\begin{array}{c}\text { Chinese } \\
\text { pronunciation }\end{array}$ & Japanese & $\begin{array}{c}\text { Japanese } \\
\text { pronunciation }\end{array}$ \\
\hline Akesu & Aksu & アクス & 阿克蘇 & アクス \\
\hline Beijing & Beijing & ベイジン & 北京 & ペキン \\
\hline Cele & Qira & ツールー & 策勒 & サクロク \\
\hline Dunhuang & Dunhuang & ドゥンフアン & 敦煌 & トンコウ \\
\hline Hefei & Hefei & フーフェイ & 合肥 & ゴウヒ \\
\hline Qingdao & Qingdao & チンダオ & 青島 & アオシマ \\
\hline Shapotou & Shapotou & シャポトウ & 沙坡頭 & シャパトウ \\
\hline
\end{tabular}

中国東部および日本国内で2001年から2002年にかけて採取した風送ダストの 大気中濃度と物理化学特性の変動

\section{金井 豊·太田充恒·上岡 晃·寺島 滋·今井 登·松久幸敬·金井三千代· 清水 洋·高橋嘉夫·甲斐憲次·徐 伯瑜·林 政彦·張 仁健 \\ 要 旨}

風送ダス卜粒子の変動や特徴を明らかにすることを目的として中国との共同研究「風送ダストの大気中への供給量評価と 気候への影響に関する研究」が開始された。我々は試料採取装置を中国の北京、青島、合肥、日本の那覇、福岡、名古屋、つ くばに設置し 2001 年 2 月から 2002 年5月まで観測を行い試料を採取した。予察的な観測結果では、0.5 $\mu \mathrm{m}$ 付近の人為起源 物質によるピークと大陸起源のダスト成分と見られる4 $-5 \mu \mathrm{m}$ 付近のピークの二山形を示し、イベントの際には後者が増加した。 ダス卜濃度の季節変動は、春期に多くなっており、青島では冬期にも時々高かった。通常期の日本各地におけるダス卜濃度は さほど差はなく、中国との差の方が大きかった。ダストイベントがおきたIOPの時期には粗粒の割合が増え、濃度は北京＞青島 $>$ 合肥、北京 $>$ 福岡 > 名古屋>つくば>那覇の順にある傾向が見られた。ダス卜の主な水溶性化学成分は、細粒では硫酸ア ンモニウム、粗粒では塩化ナトリウムや硝酸ナリリウムと推定された。不溶性成分の粗粒ではアルミニウム濃度が高く、鉱物質 であることを示唆していた。 